\title{
Judicial Review and Money Bills
}

No. 192

07-Mar-2017

Pratik Datta, Shefali Malhotra and Shivangi Tyagi

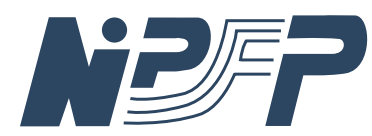

National Institute of Public Finance and Policy New Delhi 


\title{
Judicial Review and Money Bills
}

07 March 2017

\begin{abstract}
Under the Constitution of India, for a bill to be enacted

Pratik Datta, Shefali Malhotra and Shivangi Tyagi

National Institute of Public Finance and Policy, New Delhi prat.nujs@gmail.com, shefali.malhotra@nipfp.org.in, shivangi.tyagi@nipfp.org.in into a law, it has to be approved by both Houses of the Parliament - the Lower House (Lok Sabha) and the Upper House (Rajya Sabha). There is one exception to this general rule. A bill certified as a 'money bill' by the speaker of the Lower House can be enacted into a law by the Lower House alone, without any approval from the Upper House. The scope of what could constitute a 'money bill' is defined in the Constitution of India. Yet, it is possible that a bill which does not fall within the scope of this definition could be incorrectly certified as a 'money bill' by the speaker and enacted into a law without the approval of the Upper House. The Constitution of India categorically states that 'if any question arises whether a Bill is a Money Bill or not, the decision of the Speaker of the House of the People thereon shall be final'. Does this provision imply that the Indian Supreme Court cannot review whether the speaker's certification of a bill as a 'money bill' is correct or not? And if it is actually incorrect, can the Supreme Court not strike down such a law for being unconstitutional? These questions are of immense contemporary relevance in India and form the central research theme of this article.
\end{abstract}

The authors would like to thank K.P. Krishnan, Ila Patnaik, Somasekhar Sundaresan, A.K. Jayasankaran Nambiar, Ajay Shah, Alok Prasanna Kumar, Anirudh Burman and Shekhar Hari Kumar for helpful discussions and suggestions on improving the paper. An earlier version of this paper was presented at the Law Economics Policy Conference 2016 in New Delhi. Various inputs received from the audience during the Conference materially helped in improving the paper. Needless to say, any error or omission is attributable solely to the authors. 


\section{Introduction}

Under the Constitution of India, for a bill to be enacted into a law, it has to be approved by both Houses of the Parliament - the Lower House (Lok Sabha) and the Upper House (Rajya Sabha). There is one exception to this general rule. A bill certified as a 'money bill' by the speaker of the Lower House can be enacted into a law by the Lower House alone, without any approval from the Upper House. The scope of what could constitute a 'money bill' is defined in the Constitution of India. Yet, it is possible that a bill which does not fall within the scope of this definition could be incorrectly certified as a 'money bill' by the speaker and enacted into a law without the approval of the Upper House. The Constitution of India categorically states that 'if any question arises whether a Bill is a Money Bill or not, the decision of the Speaker of the House of the People thereon shall be final'. Does this provision imply that the Indian Supreme Court cannot review whether the speaker's certification of a bill as a 'money bill' is correct or not? And if it is actually incorrect, can the Supreme Court not strike down such a law for being unconstitutional? These questions are of immense contemporary relevance in India and form the central research theme of this article.

The rampant use of money bills in legislation making in India came to the forefront during the enactment of the Aadhar Act, 2016. The Bill was certified as a 'money bill' by the Speaker amid stiff resistance by the opposition. ${ }^{1}$ Ultimately, the Lower House rejected the amendments suggested by the Upper House and unilaterally enacted the Aadhar Act, 2016. ${ }^{2}$ Immediately after its enactment, a writ petition was filed by Mr. Jairam Ramesh, a senior Congress leader, in the Supreme Court challenging the speaker's decision to treat the Aadhar Bill as a 'money bill'. ${ }^{3}$

The usage of money bill to enact the Aadhar Act, 2016 was not a solitary exception. In the last few years, key legislative reforms have been enacted as money bills. For instance, the Specified Bank Notes (Cessation of Liabilities) Bill, 2017, which was passed by the Lower House to fully implement the recent demonetisation scheme, was certified as a 'money bill' by the speaker. ${ }^{4}$ Moreover, the Finance Bill

\footnotetext{
${ }^{1}$ We have explained elsewhere why most of the provisions of the Aadhar Act, 2016 could come within the scope of Article $110(1)(\mathrm{g})$ of the Constitution. The only provision of the law which could cause concern is section $33(2)$, which allows disclosure of information in the interest of national security. See, Pratik Datta, Shivangi Tyagi, Shefali Malhotra 2016.

${ }^{2}$ Various commentators criticised the use of the money bill route to enact the Aadhar Act, 2016. See, M.R. Madhavan 2016; also see, Pratap Bhanu Mehta 2016; P.D.T. Achary 2016.

${ }^{3}$ The matter is currently pending before the Supreme Court. See, Supreme Court of India 2016; Some commentators have argued that enacting this Act through the money bill route was unconstitutional. See, Alok Prasanna Kumar 2016; also see, Suhrith Parthasarathy 2017.

${ }^{4}$ It may be useful to mention here that even the High Denomination Bank Notes (Demon-
} 
2017, which is to be enacted as a money bill, proposes to amend various statutes like Payments and Settlements Act, 2007 to create a Payments Regulatory Board within the Reserve Bank of India (RBI); the Reserve Bank of India Act, 1934 to allow issuance of electoral bonds by any scheduled bank; and the Securities Exchange Board of India, 1992 to expand the Securities Appellate Tribunal (SAT). Similarly, the Finance Act 2016 amended the Reserve Bank of India Act, 1934 to institutionalise the inflation targeting monetary policy framework. ${ }^{5}$ The Finance Act 2015 had effected the merger of Forward Markets Commission (FMC) with Securities and Exchange Board of India (SEBI); ${ }^{6}$ and also amended FEMA to move the regulation making powers on capital account transactions pertaining to non-debt instruments from the RBI to the Central Government as well as create a new offence for acquiring foreign exchange, foreign securities or immovable properties outside India exceeding a prescribed threshold amount. ${ }^{7}$ The revenue deficit target under the Fiscal Responsibility and Budget Management Act 2003 has been changed thrice in the past using money bills - through Finance Act 2004, Finance Act 2012 and Finance Act 2015.

Even during the passage of the Insolvency and Bankruptcy Code, 2016 (IBC), there were speculations that it would also be enacted as a money bill. Although the money bill route was not adopted for IBC, ${ }^{8}$ authoritative voices differed on whether IBC could be passed as a money bill, effectively avoiding the Upper House. Mr. Arvind Datar argued that the fact that the IBC amends fiscal statutes and provides for a grant from the Central Government, cannot make it a money bill. ${ }^{9}$ On the other hand, Mr. Harish Salve expressed surprise that IBC 'could be brought otherwise' than as a money bill. ${ }^{10}$

In this backdrop, the decision of the Supreme Court in Jairam Ramesh v. Union of India is likely to have immense implications on the implementation of vital economic policies in India. For instance, during the passage of the GST Constitution

etisation) Bill, 1978 was certified as a 'money bill'. See http://www.prsindia.org/uploads/ media/Demonetisation/MoneyBillMessagetoRS.pdf.

${ }^{5}$ Previously, this framework was part of the Agreement on Monetary Policy Framework executed between the Union Government and the Reserve Bank of India. See sections 219 to 223, Finance Act 20162016.

${ }^{6}$ See sections 131 to 135, Finance Act 20152015.

${ }^{7}$ See sections 138 to 144, Finance Act 2015 2015; even the Public Debt Management Agency was supposed to be established under this law. However, those provisions were later withdrawn. See, BS Reporter 2015.

${ }^{8}$ The Insolvency and Bankruptcy Code was referred to a joint committee of the Parliament. See, K.R. Srivats 2015.

${ }^{9}$ See, Arvind P. Datar and Rahul Unnikrishnan 2016.

${ }^{10} \mathrm{Mr}$. Salve gave an interview on this on CNBC TV 18. See https://www.youtube.com/ watch?v=szqmGWzONAs. 
Amendment Bill, the opposition demanded an assurance from the Government that it would bring the Goods and Services Tax (GST) bill as a financial bill and not as a money bill. ${ }^{11}$ No such assurance was given by the Government. Therefore, it is likely that the government is considering enacting the GST law through the money bill route. The Supreme Court's decision could have a major impact on such policy implementation strategies.

The above vignettes illustrate not only the past, current and potential future usage of money bills in India, but also underscore its potential abuses. Yet, the Indian Supreme Court has consistently refrained from exercising its judicial review powers to check such abuse. The Supreme Court has consistently held that the Speaker's certificate issued even in violation of the Constitution of India is merely an 'irregularity of procedure' and hence beyond judicial review. Effectively, if the speaker certifies each and every bill to be a 'money bill', practically dispensing with the need for the Upper House, the Supreme Court will not intervene.

In this backdrop, this article explores whether the judicial review power of the Supreme Court could be used as an institutional check to prevent such potential abuses of money bills. For a well-rounded perspective, it traces the evolution of the legal requirement of the Speaker's certification of a bill as 'money bill' across British constitutional history and its influence on the Indian constitutional jurisprudence. The article then highlights the inherent contradiction within the Supreme Court's own jurisprudence on judicial review of legislative proceedings and the speaker's certificate on money bills. It finds that the Court has consistently differentiated between 'irregularity of procedure' from 'procedural illegality' and exercised judicial review over legislative proceedings 'tainted on account of substantive illegality or unconstitutionality'. It also finds that the Supreme Court has on multiple occasions exercised judicial review over decisions of constitutional authorities including the Speaker, which are accorded 'final' status under other provisions of the Constitution of India. Yet, these principles have never been followed in cases concerning judicial review of the Speaker's certificate on money bills. In the latter cases, the Court has not only departed from the original textual interpretation of the Constitution of India but also contradicted its own jurisprudence on judicial review of legislative proceedings. Finally, the article compares the constitutional jurisprudence on this issue across Australia, Canada, South Africa, USA and Pakistan. Study of this comparative constitutional jurisprudence shows

\footnotetext{
${ }^{11} \mathrm{P}$. Chidambaram mentioned on the floor of the House: "But we need an assurance from the government that when the bring the GST Bill they will bring it as a finance bill, not a money bill. If we have that assurance, we will help pass this Bill". This is important. The states do not want the 18 percent standard rate to be mentioned in the law. The Congress is insisting. So, if the Constitution Amendment Bill is passed today, the NDA government might have been tempted to bring the Integrated GST Bill as a money bill. See, FP Staff 2016.
} 
that the jurisprudence evolved by the Indian Supreme Court is at odds with the position adopted across these common law countries. Based on these research findings, the article concludes that Jairam Ramesh $v$. Union of India offers the Supreme Court an opportunity to rectify this flaw in its own jurisprudence and settle the law regarding its powers of judicial review of the Speaker's certification of a bill as 'money bill'.

\section{The need for finality: A historical perspective}

James Madison, one of the Founding Fathers of the United States, had best articulated the rationale for a bicameral legislature comprising a directly elected Lower House and an indirectly elected Upper House. 'A good government', Madison wrote, 'implies two things: first, fidelity to the object of government, which is the happiness of the people; secondly, a knowledge of the means by which that object can be best attained.' The Upper House helps achieve the first by ensuring that the Lower House does not forget the interests of its constituents. At the same time, being indirectly elected it also cools the impulse of sudden and violent passions of democratic masses reflected through their directly elected representatives in the Lower House. Moreover, member of the Lower House being elected directly by the people may not be acquainted with study of laws, public policy and administration. This deficiency is likely to be compensated by the indirect election of slightly older members to the Upper House. ${ }^{12}$

Consequently, in a bicameral legislative system, for a bill to be enacted into a law, it has to be approved by both Houses. 'Money bill' is an exception. The concept of 'money bill' in the Constitution of India owes its origin to the British Parliament Act, 1911. However, money bills in Britain have much older roots than the Parliament Act, 1911 itself. To better understand the reasons for attributing finality to the Speaker's decision that a bill is a 'money bill', it is essential to have a well-rounded sense of this history.

\subsection{The original sin}

Since the inception of the bicameral structure of the British Parliament, British constitutional history is replete with instances of skirmishes between the two Houses with respect to their privileges in enacting bills relating to taxation and

\footnotetext{
${ }^{12}$ See paragraph IV, James Madison 1788.
} 
public expenditure. As early as 1407, an ordinance by Henry IV called The Indemnity of the Lords and Commons mentioned that grants were 'granted by the Commons and assented to by the Lords'. ${ }^{13}$ The Judges' decision of 1489 further entrenched the power of the Commons by ruling that assent of both Houses was necessary to transform a bill into a law. ${ }^{14}$

Initially, the Commons were content simply to have grants of supply originate in their House. However, over time the Lords began 'tacking' on additional legislative provisions to Commons' bills of supply, by way of amendments. ${ }^{15}$ This led the House of Commons to assert its financial privilege through two resolutions passed by it in late seventeenth century - in $1671^{16}$ and $1678 .{ }^{17}$ Both these resolutions were aimed at curtailing the powers of the Lords to alter or amend bills of aid and supply that originate in the House of Commons.

But power corrupts. Soon the Commons realised that if they incorporate unrelated provisions to the bills of aid and supply, the Lords would have to either reject or accept the bill in its entirety since the Lords had limited right to alter or amend such bills. Since rejecting an entire bill would be politically expensive, the Lords would have to accept such bill even though additional provisions were 'tacked' on. Consequently, the Commons started incorporating within such bills provisions unconnected with the grant of aid and supply. This practice of 'tacking' was condemned by the Lords by a resolution on December 9, $1702 .{ }^{18}$ 'Tacking' being a

\footnotetext{
${ }^{13}$ It added further 'That the reports of all grants agreed to by the Lords and Commons, should be made in manner and form as hath hitherto been accustomed; that is to say, by the mouth of the Speaker of the House of Commons for the time being'. See p. 638, Sir Thomas Erskine May 1883; see also, Parliament of Canada 2016.

${ }^{14}$ See p. 7, Michael A.R. Graves 1987.

${ }^{15}$ See, Parliament of Canada 2016.

${ }^{16}$ This resolution stated: "That all aids and supplies, and aids to his Majesty in Parliament, are the sole gift of the Commons; and all bills for the granting of any such aids and supplies ought to begin with the Commons : and that it is the undoubted and sole right of the Commons to direct, limit, and appoint in such bills the ends, purposes, considerations, conditions, limitations, and qualifications of such grants; which ought not to be changed or altered by the House of Lords." See p. 641, Sir Thomas Erskine May 1883; 'Aid' refers to taxation and comprises the annual Finance Bill; 'supplies' refers to government spending and comprises the Consolidated Fund Bills. See p. 3, Select Committee on the Constitution 2011.

${ }^{17}$ See p. 3 and Appendix 2, Select Committee on the Constitution 2011; the House of Commons buttressed this resolution by restating the 'undoubted and sole right of the Commons' to deal with all bills of aids and supplies. Bills which were not confined to aids or taxation, but which imposed pecuniary burden on the people, could be amended by the House of Lords as long as the intention of the House of Commons was not altered with regards to rate or charge, its duration, mode of assessment, levy, collection, appropriation or management. See p. 642, Sir Thomas Erskine May 1883.

${ }^{18}$ It stated that: "The annexing of any clause or clauses to a Bill of Aid or Supply, the matter of which is foreign to and different from the matter of the said Bill of Aid or Supply,
} 
sensitive issue, the Commons strictly maintained its right in regard to imposition of charges upon people. They denied to the Lords the power of authorising the taking of fees and imposing pecuniary penalties, even though such provisions were necessary for general bills. Since this led to some inconvenience, a Standing Order was adopted in 1849 to accommodate for amendments that could be suggested by House of Lords in certain legislative matters. ${ }^{19}$

This arrangement did not solve the problem either. In 1860, the Commons decided to increase the property tax and stamp duties, and repeal the duties on paper as a part of the overall financial arrangement. Although the increased tax received the assent of the Parliament, the Paper Duties Repeal Bill was rejected by the Lords. This incident led to a full inquiry and consideration of the privileges of the Houses leading up to the resolution of July 6, 1860 that the right of granting aids and supplies to the crown belongs only to the Commons. ${ }^{20}$ Even this resolution was not quite decisive in granting the sole privilege of passing bills related to aids and supply to the Commons, since it did recognise the Lords' tacit power to reject various provisions to safeguard against 'tacking'. Consequently, the question on privileges still remained open for posterity to decide.

is unparliamentary and tends to the destruction of constitutional Government." See Standing Order 53, Select Committee on the Constitution 2011.

${ }^{19}$ The resolution stated: That with respect to any bill brought to this house from the House of Lords, or returned by the House of Lords to this house, with amendments, whereby any pecuniary penalty, forfeiture, or fee, shall be authorised, imposed, appropriated, regulated, varied, or extinguished, this house will not insist on its ancient and undoubted privilege, in the following cases: (1) Where the object of such pecuniary penalty or forfeiture is to secure the execution of the Act, or the punishment or prevention of offences; (2) Where such fees are imposed in respect of benefit taken, or service rendered, under the Act, and in order to the execution of the Act, and are not made payable into the treasury or exchequer, or in aid of the public revenue, and do not form the ground of public accounting by the parties receiving the same, either in respect of deficit or surplus; (3) When such bill shall be a private bill for a local or personal Act. See pp. 646-647, Sir Thomas Erskine May 1883.

${ }^{20}$ This resolution stated: (1) That the right of granting Aids and Supplies to the Crown is in the Commons alone, as an essential part of their Constitution; and the limitation of all such Grants, as to the matter, manner, measure, and time, is only in them. (2) That, although the Lords have exercised the power of rejecting Bills of several descriptions relating to Taxation by negativing the whole, yet the exercise of that power by them has not been frequent, and is justly regarded by this House with peculiar jealousy, as affecting the right of the Commons to grant the Supplies and to provide the Ways and Means for the Service of the year. (3) That, to guard for the future against an undue exercise of that power by the Lords, and to secure to the Commons their rightful control over Taxation and Supply, this House has in its own hands the power so to impose and remit Taxes, and to frame Bills of Supply, that the right of the Commons as to the matter, manner, measure and time, may be maintained inviolate. See, Tax Bills - Resolutions 1860. 


\subsection{Parliament Act, 1911}

Exactly after around half a century, the debate resurfaced. This time, the crisis resulted when the House of Lords rejected the annual finance bill as passed by the Commons in 1909. The crisis eventually led to passage of the Parliament Act of 1911, which essentially deprived the House of Lords of the right to reject money bills.

\subsubsection{Rejection of the People's Budget}

The 1909 budget, also known as 'People's Budget', was the brainchild of the then Liberal British Prime Minister H.H. Asquith and the Chancellor of Exchequer David Lloyd George. ${ }^{21}$ The Budget was aimed at recapturing the working class electorate. ${ }^{22}$ Consequently, the new tax burdens were mainly under direct taxes which would mostly affect the wealthier sections of the society. ${ }^{23}$

Naturally, the People's Budget ruffled many feathers. ${ }^{24}$ The leaders in the House of Lords felt that they had to do something to stop the budget or practically cease to be a second chamber. ${ }^{25}$ On September 8, 1909, the Cabinet discussed

\footnotetext{
${ }^{21}$ The Budget is an omnibus bill including all the revenue matters for the year. This process of consolidating all the revenue measures into a single bill began at the end of the eighteenth century but was not fully realised until 1861. See p. 98, Neal Blewett 1972.

22 At the time, the Exchequer was also faced with a current deficit, an expected lower tax yield in the coming year, increased expenditure on the navy and the cost of Old Age Pensions. See pp. 68-69, Neal Blewett 1972.

${ }^{23}$ Approximately $75 \%$ of the tax increase would be paid by the income-tax paying class, approximately $10 \%$ of the population. The land taxes were specifically meant to outwit the Lords. The Lords had earlier opposed passage of the Valuation Bill. Lloyd George's intention was to bypass the Lords by putting the provisions on land valuation in the Finance Bill. On March 13, 1909, Lloyd George told his colleagues: 'It is now clear that it would be impossible to secure the passage of a separate Valuation Bill during the existence of the present Parliament, owing to the opposition of the Lords, and therefore the only possible chance which the Government have of redeeming their pledges in this respect is by incorporating proposals involving valuation in the Finance Bill'. See p. 70, Neal Blewett 1972.

${ }^{24}$ First, the landed interests were incensed with these measures. The agricultural interest was slowly recovering from a protracted economic depression, its political power was in the decline. They saw land valuation as the ultimate threat. Second, the licensed trade saw this measure as a revenge for defeating the last year's Licensing Bill. They worked relentlessly and paid handsomely to defeat the Budget. Third, the financial and commercial interests of the City of London were opposed to the sinking fund proposals, the super-tax and increases in income tax and death duties. See p. 77, Neal Blewett 1972.

${ }^{25}$ This was mentioned in a letter by the eminent jurist Professor Dicey. See p. 79, Neal Blewett 1972.
} 
the possibility of rejection of the Finance Bill by the House of Lords for the first time. $^{26}$

On November 4, 1909 the House of Commons passed the Finance Bill. ${ }^{27}$ On November 22, 1909, Landsdowne moved an amendment in the House of Lords stating 'That this House is not justified in giving its consent to this Bill until it has been submitted to the judgement of the country'. ${ }^{28}$ On November 30, 1909, by 350 to 75 votes the Lords refused their consent to the Budget. ${ }^{29}$

\subsubsection{Passage of the Parliament Act, 1911}

The ruling party could not face a second election with the Budget unpassed and policy on House of Lords still undefined. A government whose Finance Bill is rejected can only resign or dissolve Parliament, because without money it is impossible to govern. At an election meeting held in the Albert Hall on December 10, 1909, Prime Minister Asquith impressed on his audience that one of the most important issues in the election was 'the effective limitation and curtailment of the legislative powers of the House of Lords'. He remarked: 'We shall not assume office and we shall not hold office unless we can secure the safeguards which experience shows us to be necessary for the legislative utility and honour of the party of progress. ${ }^{30}$

By the middle of March 1910 three resolutions were approved by the Cabinet. One of these resolutions provided that the Lords could neither reject nor amend a money bill. ${ }^{31}$ On May 15, 1911, the Bill was adopted by the Commons and sent to

\footnotetext{
${ }^{26}$ The financing difficulties that would arise out of such rejection were considered and no decision could be arrived at. However, the Unionist leaders were concerned more with politics than with constitutional probity. In this they were supported by Professor A.V. Dicey, himself an Unionist, who remarked 'In constitutional as in international law it is often a question rather of power than of right'. Similar flexibility in approach was shown by other constitutional lawyers. Sir Frederick Pollock who remarked 'All things are lawful for me but all things are not expedient'. Sir William Anson disapproved of the force of constitutional customs. See p. 95, Neal Blewett 1972 .

${ }^{27}$ See, Lucas Prakke 2006.

${ }^{28}$ See pp. 98-99, Neal Blewett 1972.

${ }^{29}$ And at least two-thirds of those voting for rejection owned 5000 acres of land or more. See p. 77, Neal Blewett 1972 .

${ }^{30}$ The elections were held in January 1910. The Liberals had lost their absolute majority, but were able to remain in power because they were supported by the Irish Nationalists and Labour. It was clear, though, that the Irish parliamentary party would now insist on Home Rule with much greater urgency, and to render that possible it was necessary to muzzle the House of Lords. This led to the introduction of the Parliament Bill in March 1910. See, Lucas Prakke 2006.

${ }^{31}$ The other two resolutions were that the Lords could only delay other bills which would
} 
the Lords. ${ }^{32}$ Amendments were suggested by the Lords. Fervent lobbying ensued. At the end, the Parliament Act, 1911 was passed through the House of Lords with the help of King George V's threat to pack the peerage in order to overwhelm the opposition in the Lords. ${ }^{33}$

\subsubsection{Provisions of the Parliament Act, 1911}

The Parliament Act, 1911 comprises a preamble followed by eight sections. The Preamble explicitly states that the Act aims to regulate the relations between the two Houses of Parliament. And that this Act was enacted for 'restricting the existing powers of the House of Lords'. Section 1 is on the powers of House of Lords as to 'money bills'. Under this section the Lords could delay a 'money bill' for a maximum of only one month. For the first time, 'money bill' was defined by statute. ${ }^{34}$ Effectively, it defines a bill to be a 'money bill' if in the 'opinion of

become law without the Lords' assent if passed in three successive sessions by the Commons, provided that two years had elapsed between a bill's introduction and its final approval by the Commons; and finally that the maximum duration of a Parliament should be reduced from seven years to five. See p. 152, Neal Blewett 1972.

${ }^{32}$ Due to dissolution of the Parliament in November 1910, the Parliament Bill had to be reintroduced in exactly the same form in 1911. Lucas Prakke 2006.

${ }^{33}$ Lord Morley read out a statement from the King's secretary, Aurthur Bigge, on the floor of the House which made it clear that every vote given against the bill would be a vote for a large and prompt creation of peers. See, Lucas Prakke 2006; also see, Anupam Chander 1991.

${ }^{34}$ 'Money Bill means a Public Bill which in the opinion of the Speaker of the House of Commons contains only provisions dealing with all or any of the following subjects, namely, the imposition, repeal, remission, alteration, or regulation of taxation; the imposition for the payment of debt or other financial purposes of charges on the Consolidated Fund, or on money provided by Parliament, or the variation or repeal of any such charges; supply; the appropriation, receipt, custody, issue or audit of accounts of public money; the raising or guarantee of any loan or the repayment thereof; or subordinate matters incidental to those subjects or any of them. In this subsection the expressions taxation, public money, and loan respectively do not include any taxation, money, or loan raised by local authorities or bodies for local purposes.' This provision has been amended by the National Loans Act, 1968 to include the words 'the National Loans Fund'. See Section 1(2), Parliament Act, 1911 1911; Irrespective of the statutory definition, the expression 'money bill' has a well-established meaning in the House of Commons. In its widest sense it means a bill the main purpose of which is either to impose a charge upon public funds or to impose a charge upon the people, i.e. a tax. There are many bills which are not money bill in the Parliamentary sense but would be so under the statute. For example, Public Building Expenses Bill, 1913, Agricultural Improvement Grants Bill of session 1958-59. [It is important to note that money bills and supply bills are separate categories, but there is some overlap. Money bills cover a large and increasing class of bills which impose charges upon the Consolidated Fund or on moneys provided by Parliament. A bill exclusively for this purpose is a money bill. On the other hand, a bill of aids and supplies, such as Finance Bill, is not necessarily a money bill for it may and often does include dealing with other subjects than those 
the speaker' it contains 'only' certain specific provisions. Therefore, whether a bill under the Act is a 'money bill' or not is based on the subjective opinion of the speaker.

Under section 1(3) of the Act, the Speaker has a duty to 'consult, if practicable, two members to be appointed from the Chairmen's Panel', that is, two senior backbenchers, usually one from either side of the House, appointed by the Committee of Selection from amongst those senior Ministers who chair general committees. The Speaker is under no statutory duty to consult further, but in practice, the Speaker takes the advice of the clerks of the House of Commons when deciding whether to certify a bill as a money bill. However, the Speaker can only decide whether or not to certify a bill as a money bill once it has passed the House. ${ }^{35}$ Section 3 gives legal conclusivity to the Speaker's certificate. It states:

Any certificate of the Speaker of the House of Commons given under this Act shall be conclusive for all purposes, and shall not be questioned in any court of law.

Evidently, a court of law cannot question the speaker's certificate under section 3. The principle embedded in this section closely resembles the 'enrolled bill' doctrine which had been developed by English courts, starting from the 1616 decision in King v. Arundel. This doctrine owes its origin to the English monarchical system of government. Acts passed by Parliament would receive the King's assent and be marked with the regal seal. The King being the sovereign, no one could question the regal seal. Also, in those days, the King's seal was the best evidence of the original record of the enactment. It was in this unique political and historical context that the English courts expressed reluctance to question the King's seal and review the enactment process based on extrinsic evidence about parliamentary proceedings. ${ }^{36}$ Section 3 of the Parliament Act, 1911 gives the speaker's certificate the same status as the regal seal - conclusivity for all purposes and immunity from judicial review.

To further clarify that any 'money bill' must have the consent of the Commons and the Commons only, section 4 requires every money bill to have the following words of enactment:

enumerated in the definition of money bill. Therefore, bills for aid and supply are not subject to the Parliament Act, 1911, unless they are money bills. It is, indeed, more often than not the case that the Speaker's certificate is withheld from a Finance Bill. See pp. 789-791, Sir Thomas Erskine May 1883; Finance Bills, which may contain administrative provisions in addition to the matters specified in section 1(2) of the 1911 Act, are quite frequently not certified as money bills. See paragraph 10, Select Committee on the Constitution 2011.

${ }^{35}$ See paragraph 11, Select Committee on the Constitution 2011.

${ }^{36}$ See pp. 217-218, David Sandler 2008. 
Be it enacted by the King's most Excellent Majesty, by and with the advice and consent of the Commons in this present Parliament assembled, in accordance with the provisions of the Parliament Act, 1911, and by authority of the same, as follows. ${ }^{37}$

However, as a matter of procedure, even after a bill has been certified as a 'money bill', the Lords can amend such bill within one month but the Commons are not obliged to consider the amendments. ${ }^{38}$

The statutory concept of 'money bill' and the speaker's certification of a bill as 'money bill' introduced by the British Parliament in the Parliament Act, 1911 ultimately found its way into the Constitution of India, albeit with crucial modifications.

\section{Contradictory jurisprudence under Constitu- tion of India}

Before the advent of the Constitution of India, British India was governed by the Government of India Act, 1935, which became effective in 1937. The Act created a Federal Legislature consisting of His Majesty represented by the Governor-General and two chambers - the Council of States (Upper House) and Federal Assembly (Lower House). The Upper House consisted of one hundred and fifty-six representatives of British India and not more than one hundred and four representatives of the Indian States. The Lower House consisted of two hundred and fifty representatives of British India and not more than one hundred and twenty-five representatives of the Indian States. ${ }^{39}$ Section 37 of the Government of India Act, 1935 provided for special provisions as to 'financial bills'. Section 38 empowered each chamber of the Federal Legislature to make rules regulating 'their procedure and the conduct of their business' subject to the provisions of the Government of India Act, 1935. Section 41 of Government of India Act, 1935 had a general prohibition preventing courts from inquiring into legislative proceedings 'on the ground

\footnotetext{
${ }^{37}$ This provision has been amended to replace 'the Parliament Act, 1911' with 'the Parliaments Act 1911 and 1949' also. See Section 4, Parliament Act, 19111911.

${ }^{38}$ See paragraph 13, Select Committee on the Constitution 2011; In a bid to protect the existing rights and privileges of the House of Commons, section 6 of the Act provides: Nothing in this Act shall diminish or qualify the existing rights and privileges of the House of Commons. This section protects the Commons' claim to privilege by which the Lords are debarred from amending bills of aids and supplies, since these bills are not 'money bills'. See, Sir Thomas Erskine May 1883.

${ }^{39}$ See section 18, Government of India Act, 19351935.
} 
of any alleged irregularity of procedure' ${ }^{40}$ It is worthwhile to note that under the Government of India Act, 1935 there was no provision on certification of a bill as 'financial bill' by a speaker. Instead, a 'financial bill' could be introduced in the Lower House only on recommendation of the Governor-General. This position was to undergo a drastic change under the Constitution of India.

\subsection{Drafting of the Constitution of India}

The Constitution of India was drafted by the Constituent Assembly. This Constituent Assembly appointed a number of committees to consider and report on various important matters for which constitutional provisions would be necessary. These committees submitted their reports during April to August 1947. Based on the decisions of the Assembly on these reports, the Constitutional Advisor prepared a draft constitution which was placed before the Drafting Committee on October 27, 1947. Article 74 of this draft provided for a special procedure in respect of money bill. The draft article was inspired by Article 21 of the Constitution of Ireland, 193\%. Article 75 of this draft provided a definition of money bill, which was inspired by section 37 of the Government of India Act, 1935, section 53 of the Commonwealth of Australia Constitution Act, 1900 and Article 22 of the Constitution of Ireland, $1937 .{ }^{41}$ This draft Art. 75 provided that 'if any question arises whether a Bill is a Money Bill or not, the decision of the Speaker of the House of the People thereon shall be final'. ${ }^{42}$

It is noteworthy that neither section 37 of the Government of India Act, 1935 nor section 53 of the Commonwealth of Australia Constitution Act, 1900 has a similar provision making the decision of the speaker final. Only Article 22 of the Constitution of Ireland, 1937 has a similar provision. The Chairman of the Irish Lower House has the power to certify a bill which in his opinion is a 'money bill'. And his certificate is 'final and conclusive' subject to the other provisions of that article. The article then goes on to lay down a unique procedure of dispute resolution if the Upper House disputes the certificate of the Chairman. ${ }^{43}$ The draft

\footnotetext{
${ }^{40}$ Section $41(1)$ states: "The validity of any proceedings in the Federal Legislature shall not be called in question on the ground of any alleged irregularity of procedure." See, Government of India Act, 19351935.

${ }^{41}$ The side note to Article 75 of the Draft Constitution by the Constitutional Adviser mentioned this. See p. 32, B. Shiva Rao 2012.

${ }^{42}$ See, B. Shiva Rao 2012.

${ }^{43}$ The article allows the Upper House the option to pass a resolution, by not less than thirty sitting members, requesting the President to refer the question whether a bill is a money bill or not to a Committee of Privileges. The President, in consultation with the Council of States, may accept the request. In that event, the President in consultation with the Council of State,
} 
prepared by the Indian Constitutional Adviser only adopted the part on finality of the certification of a bill as a money bill by the speaker from the Constitution of Ireland, 1937 but did not adopt the Irish model of dispute resolution.

On December 5, 1947, the Expert Committee on Financial Provisions submitted its report to the President of the Constituent Assembly. With respect to money bills, the Committee suggested that when a money bill is sent from the Lower House to the Upper House, a certificate of the speaker of the Lower House saying it is a money bill should be attached to or endorsed on the bill to avoid controversies 'about the matter outside the Lower House'. Accordingly, it suggested a similar provision as in the Parliament Act, 1911 be inserted in the Constitution of India. ${ }^{44}$ Based on the recommendations of the Expert Committee on Financial Provisions, Clause 75 was also revised to add a new sub-clause to provide for the endorsement of a certificate by the speaker on a money bill before its transmission to the Council of States and its presentation to the President for assent. ${ }^{45}$ Therefore, it can be concluded that the reason for insertion of the speaker's certificate before transmission of a money bill to the Upper House was to avoid any controversy on the issue in the Upper House and before the President.

Further, in the draft constitution prepared by the drafting committee, Article 101 provided for immunity of Parliamentary proceedings from judicial intervention on 'alleged irregularity of procedure'. ${ }^{46}$ This article finally got renumbered as Article 122 in the Constitution of India. During the Constituent Assembly Debates, Shri H.V. Kamath suggested an amendment to draft Article 101 to clarify that the validity of any Parliamentary proceedings shall not be called in question in any

must appoint a Committee of Privileges consisting of equal number of members from the Upper and Lower Houses and chaired by a judge of the Supreme Court. The Supreme Court judge as the Chairperson has a right to vote only if there is an equality of votes. The Committee of Privileges has to report its decision within twenty-one days after the day on which the Bill was sent to the Upper House. Such decision shall be final and conclusive. If the President, in consultation with the Council of States, decides not to accede to the request of the Upper House, or if the Committee of Privileges fails to report within the specified time limit, the certificate of the Chairman of the Lower House stands confirmed. See Article 22, Constitution of Ireland, 1937 1937, Further, Article 26 of the Irish Constitution provides the President the power to refer a bill to the Supreme Court to examine its constitutionality. However, money bill is specifically exempted for such Presidential reference.

${ }^{44}$ See p. 281, B. Shiva Rao 2012.

${ }^{45}$ See pp. 357-358, B. Shiva Rao 2012.

${ }^{46}$ This corresponds to Article 122 of the Constitution of India. Draft Article 101 stated: '(1) The validity of any proceedings in the Parliament shall not be called in question on the ground of any alleged irregularity of procedure. (2) No officer or other member of Parliament in whom powers are vested by or under this Constitution for regulating the procedure or the conduct of business, or for maintaining order, in Parliament shall be subject to the jurisdiction of any court in respect of the exercise by him of those powers.' See p. 553, B. Shiva Rao 2012. 
court. ${ }^{47}$ Accordingly he suggested that the words 'called in question' be replaced with 'called in question in any court'. Refuting this suggested amendment, Dr. B.R. Ambedkar categorically stated: ${ }^{48}$

Sir, with regard to the amendment of Mr. Kamath, I do not think it is necessary, because where can the proceedings of Parliament be questioned in a legal manner except in a court? Therefore the only place where the proceedings of Parliament can be questioned in a legal manner and legal sanction obtained is the court. Therefore it is unnecessary to mention the words which Mr. Kamath wants in his amendment.

For the reason I have explained, the only forum there the proceedings can be questioned in a legal manner and legal relief obtained either against the President or the Speaker or any officer or Member, being the Court, it is unnecessary to specify the forum. Mr. Kamath will see that the marginal note makes it clear.

This is a categorical clarification that Article 122 of the Constitution of India contemplates judicial review by courts over legality of Parliamentary proceedings except on 'the ground of any alleged irregularity of procedure'.

\subsection{Textual reading of Constitution of India, 1949}

Article 110(1) defines a money bill. Art. 109 of the Constitution of India provides for the special procedure in respect of money bills. It prohibits introduction of money bills in the Upper House. It can be introduced only in the Lower House. After passage in the Lower House, it must be transmitted to the Upper House for its recommendations. Art. 110(4) provides that when a money bill is transmitted from the Lower House to the Upper House, it must be endorsed with a certificate of the speaker of the Lower House that it is a money bill. The Upper House must within fourteen days of such receipt return the bill to the Lower House with its recommendations. The Lower House may either accept or reject any or all of the recommendations made by the Upper House. The final bill as accepted by the Lower House, with or without amendments suggested by the Upper House, will be deemed to have been approved by both the Houses. If the Upper House fails to return the bill along with the recommendations within fourteen days, the bill as passed by the Lower House will be deemed to have been passed by both the

\footnotetext{
${ }^{47}$ See proceedings dated May 23, 1949, Parliament of India 2016.

${ }^{48}$ See proceedings dated May 23, 1949, Parliament of India 2016.
} 
Houses. Under Art. 111, when a money bill has been passed by the Lower House it shall be presented to the President along with the speaker's certificate for his assent.

Similarly, there are corresponding provisions in the Constitution of India for money bills introduced in and passed by a State Legislative Assembly. Article 198 provides for the special procedure for money bills in the State Legislative Assembly, while Art. 199 defines a money bill and also provides for finality of the decision of the speaker of the Legislative Assembly. When a money bill has been passed by the State Legislative Assembly, Article 200 requires it to be presented to the Governor, along with the speaker's certificate, for his assent. ${ }^{49}$

\subsubsection{Conclusiveness of speaker's certificate}

In this backdrop, Article 110(3) of the Constitution of India states:

If any question arises whether a Bill is a Money Bill or not, the decision of the Speaker of the House of the People thereon shall be final.

This provision was inspired by Article 22 of the Constitution of Ireland, 1937 and section 3 of the Parliament Act, 1911. Article 22 of the Constitution of Ireland, 1937 states:

The Chairman of Dail Eireann shall certify any Bill which, in his opinion, is a Money Bill to be a Money Bill, and his certificate shall, subject to the subsequent provisions of this section, be final and conclusive.

The subsequent provisions of Article 22 lays down a dispute resolution mechanism which has been alluded to earlier. In other words, unless recourse is taken to raise a dispute as to whether a bill is a money bill or not and the constitutional procedure followed, the Chairman's certificate is treated as final and conclusive under the Constitution of Ireland, 193\%. In contrast, the Constitution of India does not provide for any special dispute resolution mechanism. In absence of any such special constitutional procedure for dispute resolution, excluding judicial review of the speaker's certificate would amount to an arbitrary and unreasonable interpretation of the text of the Constitution of India.

The Parliament Act, 1911 consciously avoided judicial review of the speaker's certificate. Section 3 made it abundantly clear:

${ }^{49}$ Since the critical provisions relevant for the purpose at hand are similarly worded for both the Centre and the States, they will not be treated separately in this paper. 
Any certificate of the Speaker of the House of Commons given under this Act shall be conclusive for all purposes, and shall not be questioned in any court of law.

The Indian draftsmen were aware of this text and did take it into consideration after the Expert Committee on Financial Provisions submitted its report to the President of the Constituent Assembly. The Constitution of India incorporated the conclusive nature of the speaker's decision into Article 110(3) by using the words 'shall be final', but the language used in Art. 110(3) of the Constitution of India was substantially different from section 3 of Parliament Act, 1911. Section 3 expressly excluded the judicial review jurisdiction of courts by clearly stating that the speaker's certificate 'shall not be questioned in any court of law' and that it shall be conclusive 'for all purpose'. Had the framers of the Constitution of India intended to similarly exclude judicial review jurisdiction in India, they could have used these same phrases. Yet they did not use either of those phrases in Article 110(3) of the Constitution of India.

This difference in language between the Parliament Act, 1911 and the Constitution of India could be attributed to three possible reasons. First, England follows a system of parliamentary sovereignty where the legislature is supreme. In their model it is possible to give absolute conclusivity to the speaker's certificate and immunise it from judicial review. But this would have been impossible under the Constitution of India since it was not based on parliamentary sovereignty. Giving absolute conclusivity to the speaker's certificate or decision and immunising it from judicial review in India, would have been incompatible with the overall scheme of the Constitution of India. Second, section 3 of the Parliament Act, 1911 requires complete judicial deference to the Speaker's opinion. This amounts to the judiciary relinquishing its power of judicial review - to interpret and enforce constitutional provisions of lawmaking - not to the Lower House as a whole, but to one legislative officer of the Lower House, the Speaker. Importing this provision into the Constitution of India would have amounted to an excessive delegation of judicial powers to one legislative officer in the Lower House. Such a provision would have been out of sync with the fundamental philosophy of the Constitution of India based on the tenet of separation of powers. Third, section 3 of the Parliament Act, 1911 effectively directs the English courts to conclusively presume that a bill certified by the Speaker was passed in accordance with all the procedural requirements. In England, such procedural requirements would never be of constitutional status since they do not have a written constitution. Instead, such procedures could either be in statutes passed by the Houses themselves or rules framed by each of the Houses. Therefore, the presumption under section 3 prevents English courts from reviewing whether the Houses complied with their 
own procedures. However, under the Constitution of India, the Houses have to follow not only procedures laid down by their own legislation and rules, but also by the constitution itself. Importing absolute immunity from judicial review under section 3 of the Parliament Act, 1911 would render the constitutional procedure for lawmaking redundant in the Indian context. ${ }^{50}$ For these reasons, it is logical to presume that the Indian draftsmen consciously omitted incorporating the exact language of section 3 of Parliament Act, 1911 into the Constitution of India.

Therefore, it is submitted that the framers of the Constitution of India did not intend to make the speaker's certificate 'conclusive for all purposes' as is the position in England. They were merely trying to avoid the skirmishes experienced by the Lords and the Commons in Britain for seven hundred years leading up to the enactment of the Parliament Act, 1911. In an attempt to avoid similar controversies 'about the matter outside the Lower House', the Constitution of India made the speaker's decision final for the purpose of the two Houses of the Parliament. ${ }^{51}$ By clearly omitting to mention that the speaker's certificate shall not be questioned in any court of law, the constitution framers deliberately allowed the possibility of judicial review of the speaker's decision in India.

\subsubsection{Exclusion of judicial review of legislative proceedings}

Judicial review of the speaker's certificate is not excluded by Article 122(1) either. ${ }^{52}$ Article 122(1) of the Constitution of India protects 'proceedings in Parliament' from being 'called into question on the ground of any alleged irregularity of procedure'. ${ }^{53}$ It is important to understand the meaning of the word 'procedure' in this provision. Article 118 to Article 122 have been clubbed under the heading 'Procedure Generally'. Article 118(1) empowers each House of the Parliament to make rules for regulating 'its procedure and conduct of its business' subject to the provisions of the Constitution of India. ${ }^{54}$ Article 119 empowers Parliament to enact laws to regulate the 'procedure' in Parliament in relation to financial business. Such law overrides any rule made under Article 118. In this context, Article 122(1) prohibits judicial review of 'irregularity of procedure'. Here 'procedure'

\footnotetext{
${ }^{50}$ Similar arguments have been made by Alok Prasanna Kumar. See, Alok Prasanna Kumar 2016; These arguments apply equally to the difference between the American constitutional jurisprudence and its British counterpart. See, Bar-Siman-Tov 2009.

${ }^{51}$ The same applies equally to state legislatures.

${ }^{52}$ Art. 212(1) is the corresponding provision for State Legislatures. Constitution of India 1949.

${ }^{53}$ It states: 'The validity of any proceedings in Parliament shall not be called in question on the ground of any alleged irregularity of procedure.' See, Constitution of India 1949.

${ }^{54}$ Under this provision, the Lok Sabha has issued the the Rules of Procedure and Conduct of Business in Lok Sabha.
} 
refers only to procedure in rules made under Article 118 or in a law under Article 119. Effectively, if the House chooses to make a procedure for itself, violation of such procedure by the House itself cannot be questioned in a court of law. But if the Constitution of India prescribes a procedure to be followed by a House (as in the case of money bills), violation of such constitutional procedure is not immune from judicial review under Art. 122. In other words, the phrase 'irregularity of procedure' in Art. 122 does not cover constitutional procedure. Therefore, the protection from judicial review granted by Art. 122 cannot be stretched to protect non-compliance or breach of a constitutional procedure like the special procedure for money bills under Articles 109 and 110. ${ }^{55}$

\subsubsection{Requirements as to recommendations and previous sanctions}

Article 255 of the Constitution of India protects any central or state legislation from being rendered invalid merely because 'some recommendation or previous sanction required under this Constitution' was not given, if the President or Governor had subsequently given their assent respectively. Effectively, Article 255 treats 'requirements as to recommendations and previous sanctions' as 'matters of procedure only' and therefore, outside the purview of judicial review. ${ }^{56}$ However, Article 255 does not treat the requirement of certification of a bill as 'money bill' by the speaker under Article 110(4) as a 'matter of procedure'. This is because it uses the words 'recommendation' and 'sanction' only; not 'certificate' or 'certification'. This assumes significance because in the Constitution of India, 'recommendation' and 'sanction' are given primarily by the President and Governors; never by the speaker. ${ }^{57}$

Article 255 can be traced back to the proviso to section $80 \mathrm{~A}(3)$ of the Government of India Act, 1919. Section 80A(3) required sanction of the Governor-General before the local legislature of any Province could make or take into consideration certain laws on taxation and public expenditure. The proviso however clarified that any such law made by the local legislature and subsequently assented to by the Governor-General will not be invalid merely because it did not get the previous sanction of the Governor-General. Effectively, if the Governor-General himself

\footnotetext{
${ }^{55}$ Similarly, the protection from judicial review under Art. 212 cannot be stretched to protect non-compliance or breach of a constitutional procedure like the special procedure for money bills under Articles 198 and 199.

${ }^{56}$ See p. 9060, Durga Das Basu 2012.

${ }^{57}$ Under the Constitution of India, apart from the President and Governor, 'recommendation' can also be given by the High Courts and certain specialised bodies (like National Commission for Scheduled Castes, Finance Commission, GST Council and others); 'sanction' can be given by Parliament too. See Articles 233, 338, 243-I, 246, 269A, 357, Constitution of India 1949.
} 
gave subsequent assent to the law, it would be valid irrespective of the fact that his sanction or recommendation had not been taken previously. The Government of India Act, 1935 also had a similar provision. Section 109(1) stated that even if the Governor-General or Governor had given his recommendation or previous sanction to the introduction or passing of a Bill or moving of an amendment, he can subsequently still withhold his assent to such Bill. In this context, sub-section (2) clarified that no Act of the Federal Legislature or a Provincial Legislature will be considered invalid merely because previous recommendation or sanction of the Governor-General or the Governor was not taken, if the final assent had been given by the Governor-General or Governor respectively. Again, this effectively meant that if the Governor-General or Governor himself gave subsequent assent to the law, such law would be valid irrespective of the fact that his sanction or recommendation had not been taken previously.

Both section $80 \mathrm{~A}(3)$ and section $109(2)$ treated requirements as to previous sanctions and recommendations by a constitutional authority - Governor-General or Governor - to be 'matters of procedure only', if assent of the same constitutional authority was procured subsequently. These provisions were not meant to apply to the requirement of certification by the speaker since neither the Government of India Act, 1919 nor the Government of India Act, 1935 had any mention of such speaker's certificate. Further, under the Constitution of India, the speaker gets only one chance to certify a bill as a 'money bill' - before transmission of the bill to the Upper House. Subsequently, his assent is never required. Instead, the President's or Governor's assent is needed. Such assent by the President or Governor cannot rectify the lack of certification by a completely different constitutional authority - the speaker.

Moreover, it is evident from the drafting history that the purpose of the speaker's certificate was to avoid controversies 'about the matter outside the Lower House'. Presidential assent cannot substitute for this purpose at a later stage. Therefore, it can be concluded that Article 255 does not cover the requirement of the speaker's certificate under Article 110(4) as 'matters of procedure only'. ${ }^{58}$ In other words, Article 255 does not prevent judicial review of the speaker's certification of a bill as 'money bill'.

${ }^{58}$ Similarly, Article 255 does not cover the requirement of the speaker's certificate under Article 199(4) as 'matters of procedure only'. 


\subsection{Supreme Court on 'procedural irregularity' and 'pro- cedural illegality'}

The scope of Articles 122 (and its counterpart for States in Article 212) has come up before the Supreme Court in matters concerning the powers, privileges and immunities of the Parliament as well as State Legislatures and their respective members under Articles 105 and 194 of the Constitution of India respectively. In these cases, the Supreme Court has consistently distinguished the phrase 'irregularity of procedure' in Articles 122 and 212 from 'procedural illegality' - a term coined by the court itself. The Supreme Court has sought to distinguish between 'procedural irregularity' and 'procedural illegality', holding that 'procedural illegality' is subject to judicial review while 'procedural irregularity' is not. It would be useful to review this strand of the Supreme Court's jurisprudence and then compare it with its interpretation of Articles 122 and 212 on matters relating to judicial review of speaker's certification of money bills.

The question arose for the first time in the case of Pandit M.S.M. Sharma v. Dr. Shree Krishna. ${ }^{59}$ This case arose out of the publication of expunged portions of the proceedings of the Bihar Legislative Assembly by the editor of Searchlight, the petitioner in this case. The matter was referred to the Committee of Privileges of the Bihar Legislative Assembly, which called upon the petitioner to show cause why he should not be proceeded for breach of privilege of the Assembly under Article 194(3) of the Constitution of India. ${ }^{60}$ The petitioner filed a writ petition before the Supreme Court for quashing of proceedings against him in the Bihar Legislative Assembly. He argued that the privilege granted to the Legislative Assembly under Article 194(3) was subject to the fundamental right to freedom of speech under Article 19(1)(a). The Supreme Court dismissed the petition holding that Article 212 of the Constitution of India prohibits the validity of any proceedings in a Legislature of a State from being called in question in a court of law on the ground of any alleged 'irregularity of procedure'.

This rather simplistic ratio had to be revisited by a seven judge bench of the court in the rather compelling factual matrix in Special Reference No. 1 of $1964 .{ }^{61}$ In this case, one Keshav Singh was committed to prison for committing breach of privilege and contempt of the Uttar Pradesh Legislative Assembly. The Uttar Pradesh High Court ordered that Keshav Singh should be released on bail. Offended by the High Court's decision, the Uttar Pradesh Legislative Assembly chose a radical

\footnotetext{
${ }^{59}$ Supreme Court of India 1960.

${ }^{60}$ Article 194 relates to the powers and privileges of the House of Legislatures. Article 194(3) gives the legislature the power to define its powers, privileges and immunities by law.

${ }^{61}$ See, Supreme Court of India 1964.
} 
path. It passed a resolution ordering the arrest of the judges of the Uttar Pradesh High Court who granted the bail order, along with the advocate representing Keshav Singh. The two judges and the lawyer approached the Allahabad High Court under Article 226 challenging the constitutionality of this resolution. A full bench of the Allahabad High Court comprising of 28 judges passed an order restraining the speaker of the Uttar Pradesh Legislative Assembly from issuing or executing a warrant pursuant to the resolution. Ultimately, the matter was referred to the Supreme Court through a presidential reference under Article 143 of the Constitution of India, wherein the Supreme Court was required to determine the scope of legislative privilege enjoyed by the State Legislative Assembly under the Constitution of India. In this context, the Supreme Court discussed the scope of immunity from judicial review under Article 212, clarifying that it is not absolute in nature. The Court held: ${ }^{62}$

Article 212(1) seems to make it possible for a citizen to call in question in the appropriate court of law the validity of any proceedings inside the legislative chamber if his case is that the said proceedings suffer not from mere irregularity of procedure, but from an illegality. If the impugned procedure is illegal and unconstitutional, it would be open to be scrutinised in a court of law, though such scrutiny is prohibited if the complaint against the procedure is no more than this that the procedure was irregular.

In face of the drastic resolution by the Uttar Pradesh State Legislative Assembly against the two judges and the lawyer, the Supreme Court had no hesitation in distinguishing 'procedural irregularity' under Article 212 from 'procedural illegality' - which includes breach of constitutional provisions. In other words, the Supreme Court's decision in Special Reference No. 1 of 1964 clearly excludes breach of constitutional provisions from the immunity granted under Article 212, allowing judicial review in such matters.

This principle was further upheld by the Supreme Court in the case of Raja Ram Pal v. Hon'ble Speaker, Lok Sabha. ${ }^{63}$ This case arose after television channels telecasted programmes depicting some members of Lok Sabha as well as Rajya Sabha accepting money for raising certain questions in the House or for otherwise espousing certain causes for those offering the money. Each House instituted inquiries through separate committees. Finally, Lok Sabha as well as Rajya Sabha expelled those members. Some of the expelled members challenged the constitutional validity of their expulsion. The Supreme Court was called upon to decide whether each House of the Parliament in exercise of its powers, privileges and immunities

\footnotetext{
${ }^{62}$ See paragraph 61, Supreme Court of India 1964.

${ }^{63}$ See, Supreme Court of India 2007.
} 
under Article 105 of the Constitution of India could expel its own members from membership of the respective House. And if such power exists, whether exercise of such power is subject to judicial review. The Supreme Court observed that " $T$ The proceedings which may be tainted on account of substantive illegality or unconstitutionality, as opposed to those suffering from mere irregularity thus cannot be held protected from judicial scrutiny by Article 122(1)'.64 The court limited the scope of immunity of legislative proceedings from judicial review under Article 122 by holding: 65

Any attempt to read a limitation into Article 122 so as to restricts the court's jurisdiction to examination of the Parliament's procedure in case of unconstitutionality, as opposed to illegality would amount to doing violence to the constitutional text. Applying the principle of 'expressio unius est exclusio alterius' (whatever has not been included has by implication been excluded), it is plain and clear that prohibition against examination on the touchstone of 'irregularity of procedure' does not make taboo judicial review on findings of illegality or unconstitutionality.

Evidently, in matters concerning powers, privileges and immunities of the Parliament as well as State Legislatures and their respective members under Articles 105 and 194 of the Constitution of India, the Supreme Court has distinguished between 'procedural irregularity' and 'procedural illegality'. It has clearly accepted that Articles 122 and 212 do not impose absolute bar on judicial review, especially when the allegation is one of breach of constitutional procedure. Yet, when the occasion required the Supreme Court to review the speaker's decision on whether a bill is a money bill or not, the Supreme Court has evolved a markedly contrarian jurisprudence against judicial review.

\subsection{Supreme Court on judicial review of 'final' decisions}

The Constitution of India grants the status of finality to various types of decisions made by different constitutional authorities including the Supreme Court, the President, the Governor and the Speaker. In three instances the Constitution of India explicitly provides that such final decisions cannot be questioned. The decision of the Speaker as to whether a bill is a 'money bill' or not is not one of them. Moreover, the Supreme Court itself has specifically held that some of these 'final' decisions by the President, the Governor, certain empowered authorities, and

\footnotetext{
${ }^{64}$ See paragraph 238, Supreme Court of India 2007.

${ }^{65}$ See paragraph 253, Supreme Court of India 2007.
} 
the Speaker are judicial in nature and are subject to judicial review. Table 1 below gives the details of these constitutional provisions along with the relevant caselaws of the Supreme Court, wherever available.From this table it is evident that the Supreme Court has on multiple occasions held that 'final' decisions by different constitutional authorities including the Speaker could be subject to judicial review. Yet, when the occasion required the Supreme Court to review the speaker's decision on whether a bill is a money bill or not, the Supreme Court has evolved a markedly contrarian jurisprudence against judicial review. 


\begin{tabular}{|c|c|c|c|c|}
\hline 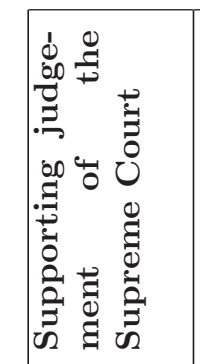 & 1 & 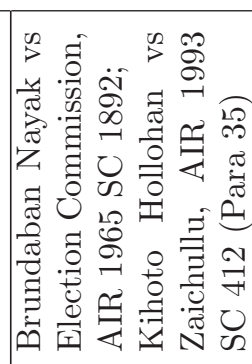 & & 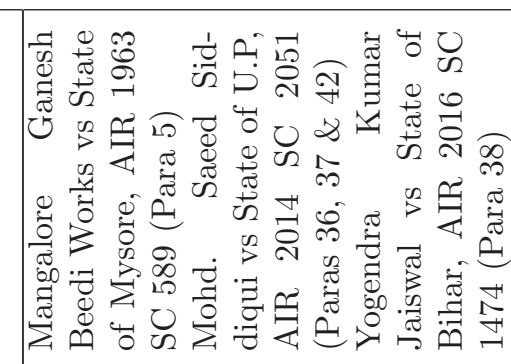 \\
\hline 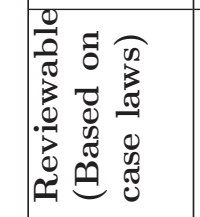 & 1 & 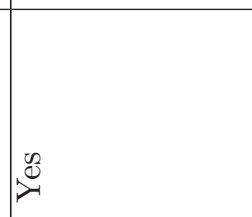 & । & $\stackrel{\circ}{2}$ \\
\hline 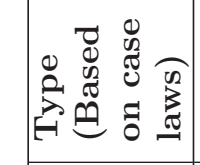 & & 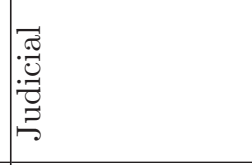 & 1 & 1 \\
\hline 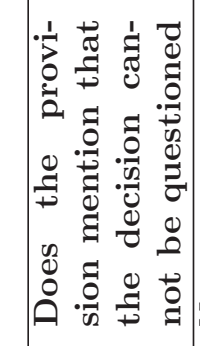 & & $\stackrel{8}{z}$ & $\stackrel{8}{z}$ & 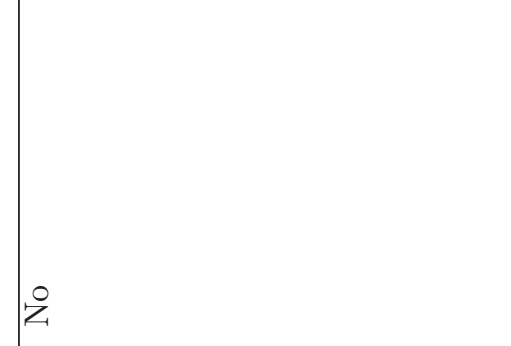 \\
\hline 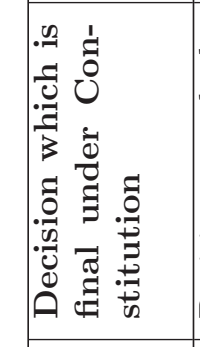 & 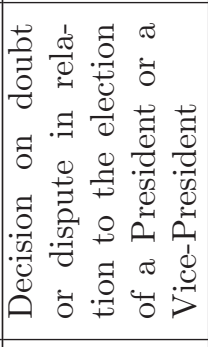 & 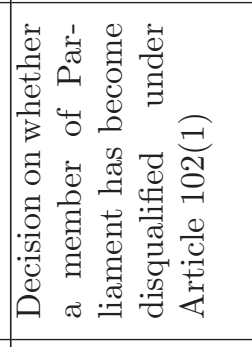 & 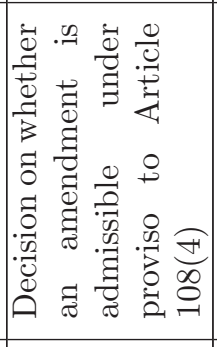 & 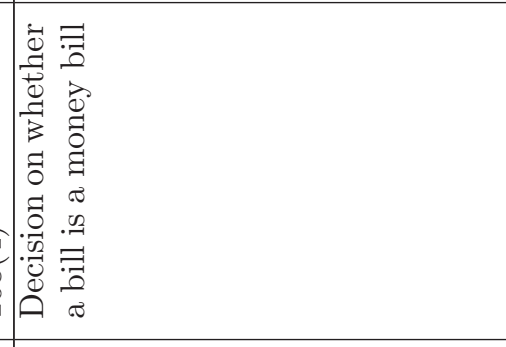 \\
\hline 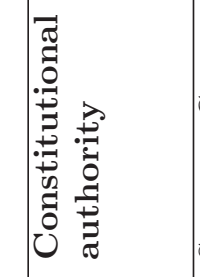 & 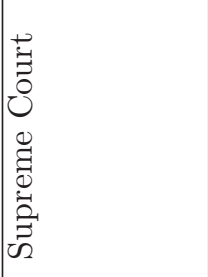 & 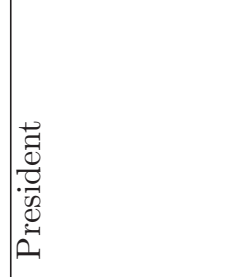 & 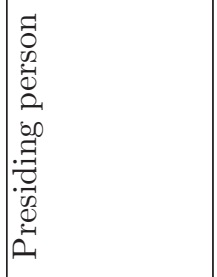 & 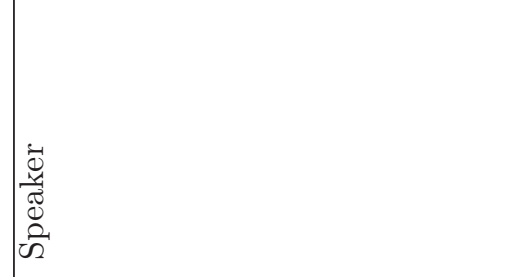 \\
\hline 尊 & $\underset{\Gamma}{\overparen{i}}$ & 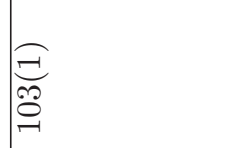 & 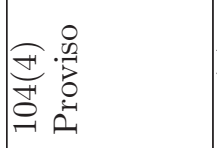 & 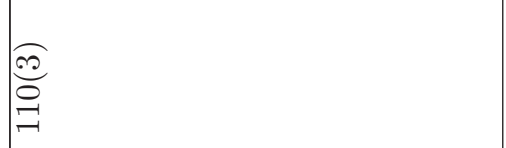 \\
\hline $\begin{array}{l}\dot{z} \\
\dot{\infty} \\
\dot{m}\end{array}$ & $\neg$ & N & $\infty$ & $\not r$ \\
\hline
\end{tabular}




\begin{tabular}{|c|c|c|c|}
\hline 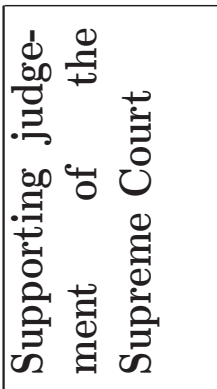 & 1 & 1 & 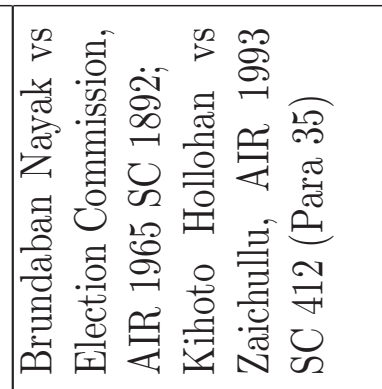 \\
\hline 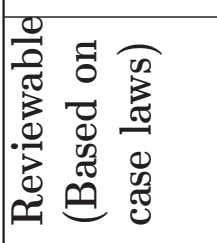 & 1 & I & $\underset{\infty}{\mathscr{C}}$ \\
\hline 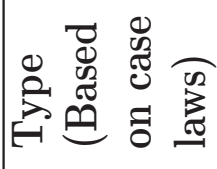 & I & I & 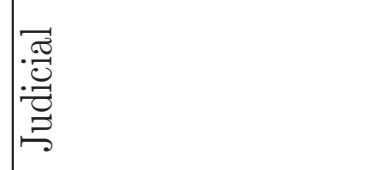 \\
\hline 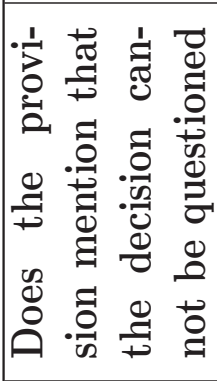 & 2 & 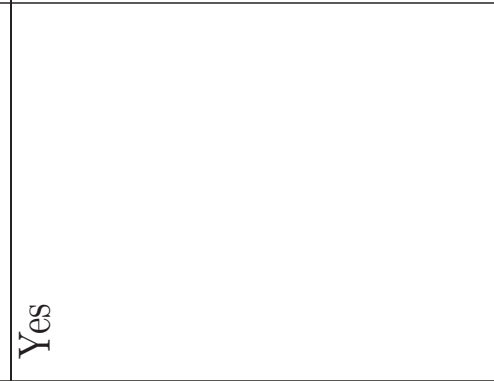 & $\stackrel{\circ}{2}$ \\
\hline 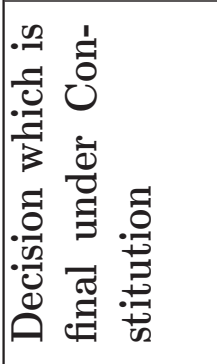 & 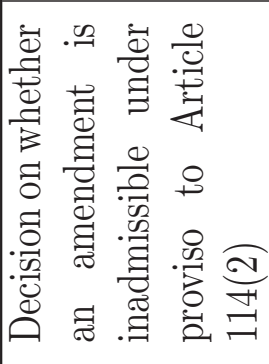 & 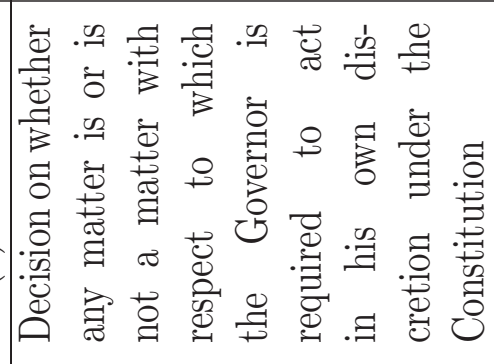 & 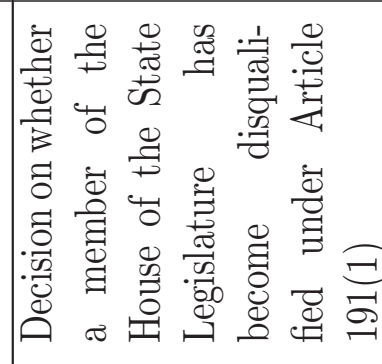 \\
\hline 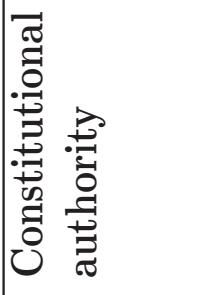 & 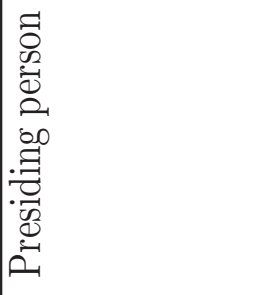 & 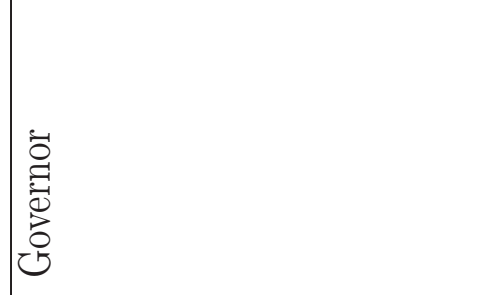 & 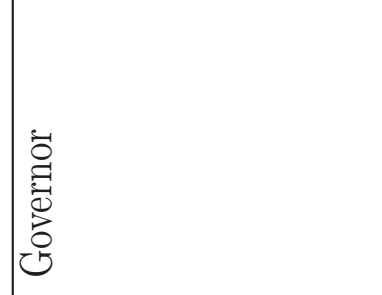 \\
\hline 惫 & $\frac{\underset{\mathcal{J}}{\Xi}}{\exists}$ & 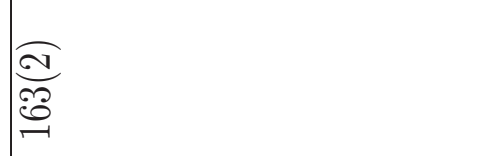 & 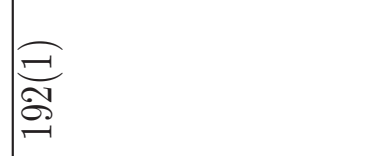 \\
\hline$\dot{\dot{n}}$ & 20 & 0 & $\curvearrowright$ \\
\hline
\end{tabular}




\begin{tabular}{|c|c|c|c|c|}
\hline 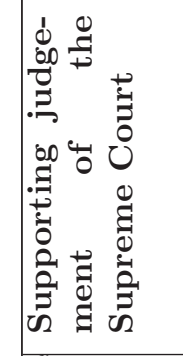 & 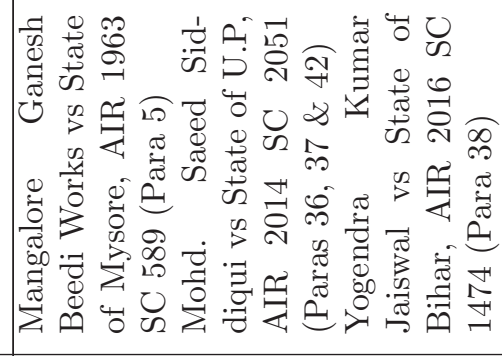 & & 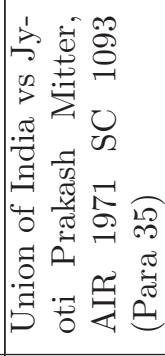 & \\
\hline 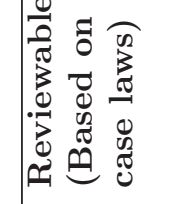 & 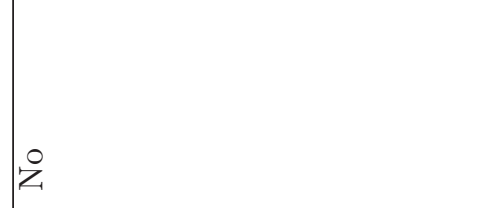 & 1 & 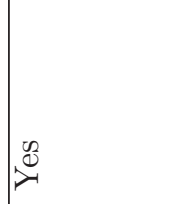 & 1 \\
\hline 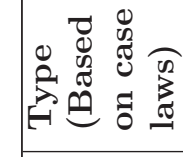 & 1 & 1 & ב⿱艹 & 1 \\
\hline 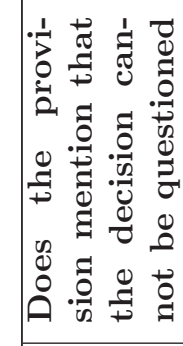 & & $\stackrel{8}{2}$ & $\AA$ & 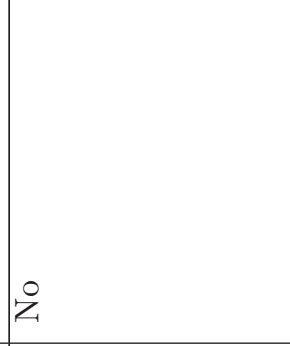 \\
\hline 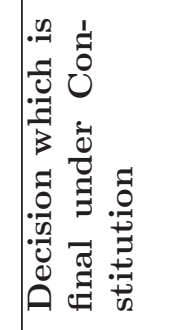 & 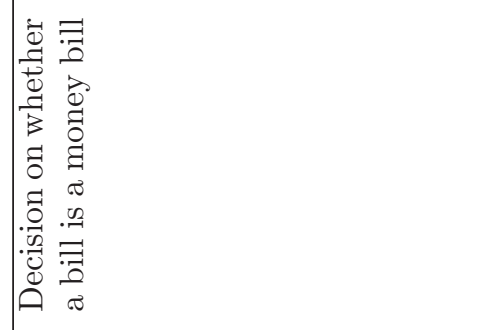 & 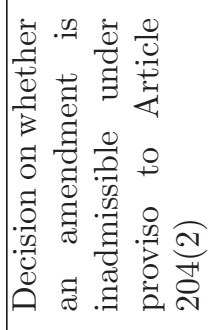 & 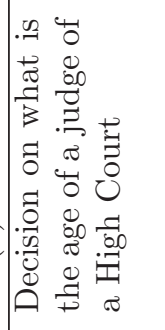 & 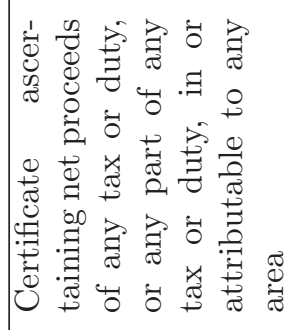 \\
\hline 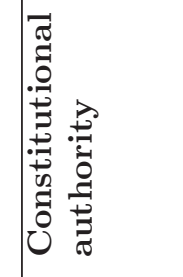 & 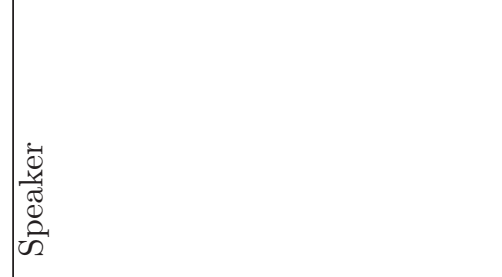 & 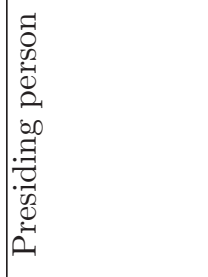 & $\mid$ & 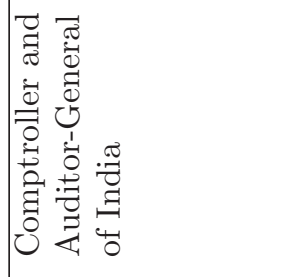 \\
\hline 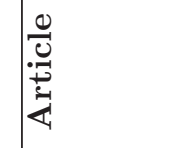 & 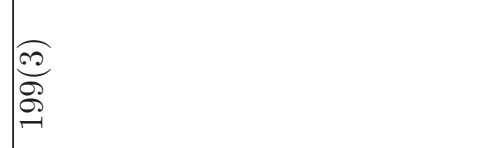 & 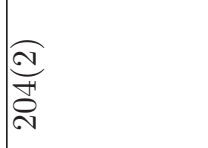 & 商 & 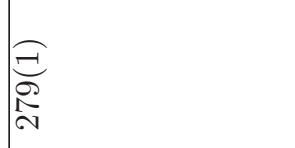 \\
\hline$\dot{a}_{\dot{m}}$ & $\infty$ & $\theta$ & 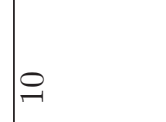 & $\exists$ \\
\hline
\end{tabular}




\begin{tabular}{|c|c|c|c|}
\hline 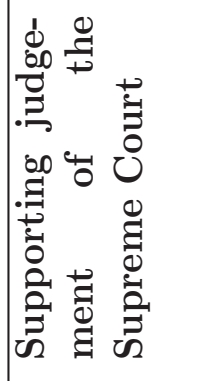 & 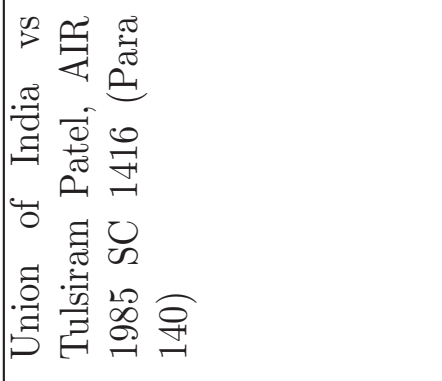 & I & । \\
\hline 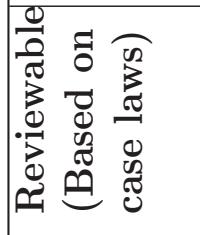 & $\underset{x}{\mathscr{x}}$ & I & । \\
\hline 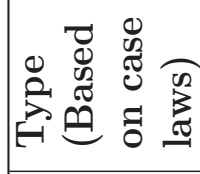 & 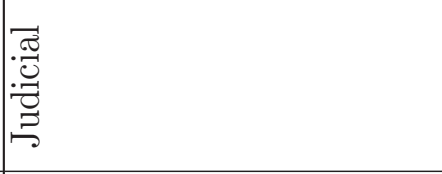 & 1 & 1 \\
\hline 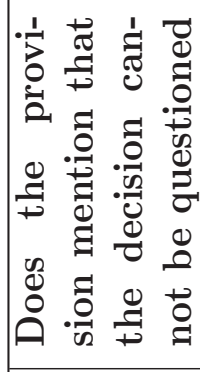 & $\stackrel{2}{2}$ & $\underset{t}{\mathscr{t}}$ & $\stackrel{\circ}{2}$ \\
\hline 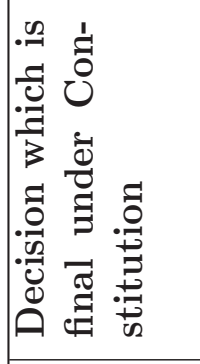 & 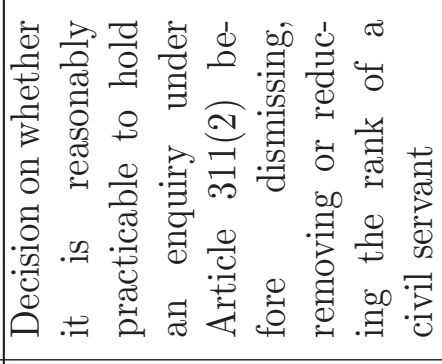 & 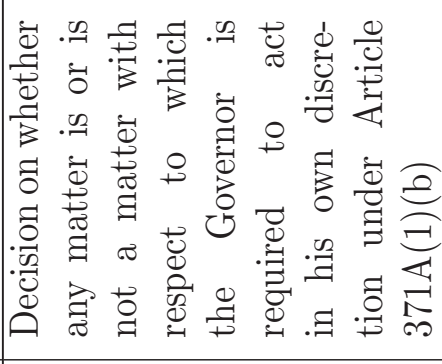 & 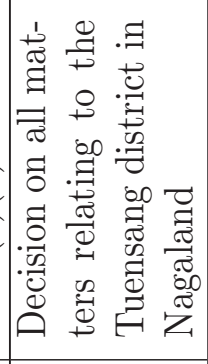 \\
\hline 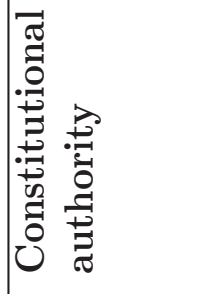 & 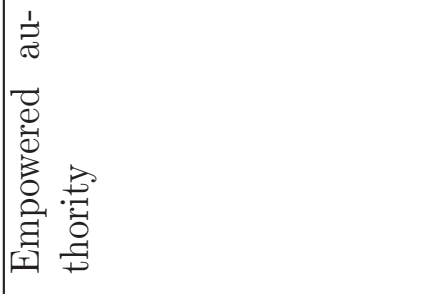 & 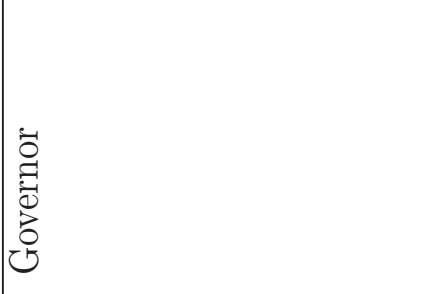 & 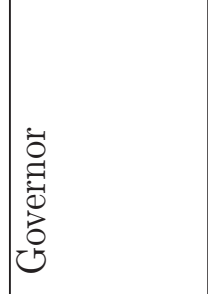 \\
\hline 惫 & $\frac{\curvearrowright}{\cdots}$ & 死 & 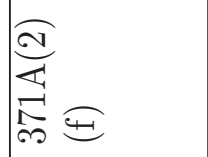 \\
\hline 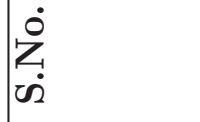 & $\stackrel{\sim}{\mathcal{I}}$ & $\ddot{9}$ & $\nexists$ \\
\hline
\end{tabular}




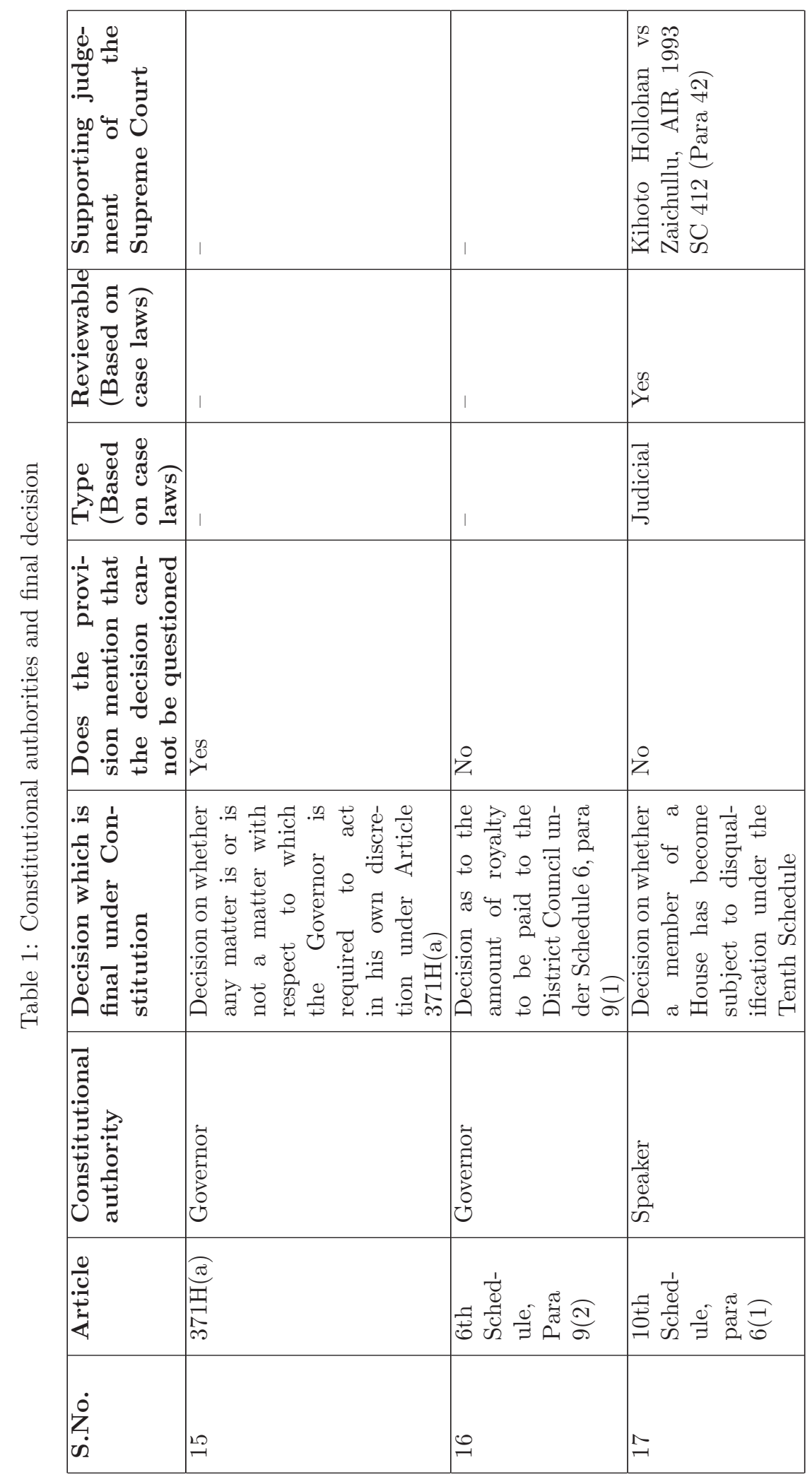




\subsection{Supreme Court on judicial review of speaker's certifi- cate}

The Supreme Court has on three previous occasions dealt with the question of whether it can exercise its judicial review powers in case of breach of the constitutional procedures in passing money bills. ${ }^{66}$ And each time the answer has been in the negative based not only on an erroneous understanding of several provisions of the Constitution of India but also a refusal to acknowledge the difference between 'procedural irregularity' and 'procedural illegality' that it itself has developed to check the abuse of legislative immunity from judicial review.

In Mangalore Ganesh Beedi Works v. State of Mysore, ${ }^{67}$ a constitution bench of the Supreme Court was asked to determine whether the Indian Coinage (Amendment) Act, 1955 was unconstitutional since it was not passed as a money bill. The appellant was a firm registered under the Mysore Sales Tax Act, 1948 under which it was liable to sales tax at the rate of 3 pies for every rupee on the turnover. Because of the Indian Coinage (Amendment) Act, 1955, the rate became 2 naya paisa per rupee, effectively imposing an additional tax burden of Rs. 25,038/on the appellant. The appellant's contention was that since this amounted to an enhancement of tax, the law should have been enacted as a money bill under Articles 198, 199 and 207 of the Constitution of India. Since no such money bill was introduced or passed for the enhancement of tax, the tax was illegal and invalid. The court held that the Indian Coinage (Amendment) Act, 1955 substituted an old coinage with a new coinage and was not a tax. However, it went on to remark:

Even assuming that it is a taxing measure its validity cannot be challenged on the ground that it offends Arts. 197 to 199 and the procedure laid down in Art. 202 of the Constitution. Article 212 prohibits the validity of any proceedings in a legislature of a State from being called in question on the ground of any alleged irregularity of procedure and Art. 255 lays down that requirements as to recommendation and previous sanction are to be regarded as matters of procedure only.

Not only was this remark by the Supreme Court an obiter dictum, it was also

\footnotetext{
${ }^{66}$ All these cases pertain to the procedure of passing money bills in the State legislature. However, since the provisions are in pari materia with the ones on the procedure of passing money bills in the Parliament, these cases laws are valid precedents for both. Articles 109, 110, 111 and 122 for money bills in the Parliament correspond to Articles 198, 199, 200 and 212 for money bills in the State Legislature. Art. 255 is applicable to both central and state laws. See, Constitution of India 1949.

${ }^{67}$ See, Supreme Court of India 1962.
} 
unnecessary and incorrect. It was unnecessary because the court had already held that the statute did not impose any tax and therefore, it could have been introduced as an ordinary bill instead of a money bill. It was incorrect because the court clearly did not apply its mind as to the potential ramifications of such a general principle that would render any violation of the constitutional procedure under Articles 197 to 199 and Article 202 immune from judicial review. As has been observed earlier, Article 212 (and its counterpart in Article 122) only restrict judicial review of 'irregularity of procedure', if such procedure is made by the Parliament through law or by each House under its rules. These articles were not intended to prevent judicial review in case of breach of constitutional procedure like the ones mentioned in Articles 197 to 199 and Article 202. Even Article 255 does not treat certification of a bill by the speaker as a 'money bill' as 'matters of procedure' immune from judicial review. The oversight of the constitution bench of the Supreme Court in this case to differentiate between constitutional procedures and other procedures in legislations or rules has been the foundation of the erroneous jurisprudence developed in subsequent decisions.

In Mohd. Saeed Siddiqui $v$. State of $U P{ }^{68}$ a three judge bench of the Supreme Court was asked to determine the constitutionality of UP Lokayukta and UpLokayuktas (Amendment) Act, 2012. The Uttar Pradesh Lokayukta and Up-Lokayuktas Act, 1975 provided a six year term for a Lokayukta. It also provided that after ceasing to hold office, the Lokayukta or Up-Lokayukta shall be ineligible for further appointment, whether as a Lokayukta or Up-Lokayukta or in any other capacity under the Government of Uttar Pradesh. After the new government entered office in 2012, the UP Lokayukta and Up-Lokayuktas (Amendment) Act, 2012 was passed as a money bill, increasing the term of the Lokayukta or Up-Lokayukta from six years to eight years or till the successor enters upon his office. It also limited the ineligibility of the Lokayuktas or Up-Lokayuktas for further appointment under the Government of Uttar Pradesh. In this backdrop, the petitioners approached the Supreme Court under Article 32 of the Constitution of India challenging the speaker's certification of the bill as 'money bill'.

The Supreme Court dismissed the petitions on the ground that 'the question whether a Bill is a Money Bill or not can be raised only in the State Legislative Assembly by a member thereof when the Bill is pending in the State Legislature and before it becomes an Act'. The Court erringly relied on incorrect obiter in Mangalore Ganesh Beedi Works v. State of Mysore to develop the following principles:

(i) the validity of an Act cannot be challenged on the ground that it offends Articles 197 to 199 and the procedure laid down in Article 202;

${ }^{68}$ See, Supreme Court of India 2014. 
(ii) Article 212 prohibits the validity of any proceedings in a Legislature of a State from being called in question on the ground of any alleged irregularity of procedure; and (iii) Article 255 lays down that the requirements as to recommendation and previous sanction are to be regarded as a matter of procedure only. It is further held that the validity of the proceedings inside the Legislature of a State cannot be called in question on the allegation that the procedure laid down by the law has not been strictly followed and that no Court can go into those questions which are within the special jurisdiction of the Legislature itself, which has the power to conduct its own business.

It placed reliance on Articles 212 and 255 to justify non-interference with the speaker's decision of certification of a bill as 'money bill' on the following ground:

As discussed above, the decision of the Speaker of the Legislative Assembly that the Bill in question was a Money Bill is final and the said decision cannot be disputed nor can the procedure of the State Legislature be questioned by virtue of Article 212. Further, as noted earlier, Article 255 also shows that under the Constitution the matters of procedure do not render invalid an Act to which assent has been given to by the President or the Governor, as the case may be. Inasmuch as the Bill in question was a Money Bill, the contrary contention by the Petitioner against the passing of the said Bill by the Legislative Assembly alone is unacceptable.

This three judge bench of the Supreme Court again failed to appreciate the difference between constitutional procedures mentioned in Articles 197 to 199 and Article 202 as against the procedures in legislations or under the rules of each House. It interpreted the words 'proceedings in the Legislature' in Article 212(1) to include 'everything said or done in either House in the transaction of the Parliamentary Business, which in the present case is enactment of the Amendment Act. ${ }^{69}$ In doing so, it converted the incorrect obiter of the constitution bench in Mangalore Ganesh Beedi Works v. State of Mysore into a binding ratio.

Next, a division bench of the Supreme Court in Yogendra Kumar Jaiswal v. State of Bihar was called upon to decide on the constitutionality of Orissa Special Courts Act, 2006. ${ }^{70}$ The Orissa State Legislative Assembly keeping in view accumulation of extensive properties disproportionate to the known sources of income by persons

\footnotetext{
${ }^{69}$ One commentator has argued that the decision of the Supreme Court in Mohd. Saeed Siddiqui v. State of UP is wrong for this precise reason. See, Alok Prasanna Kumar 2016; another commentator has argued that the judgement of the Supreme Court in Mohd. Saeed Siddiqui v. State of UP fails to rectify a constitutional error. See, Suhrith Parthasarathy 2017.

${ }^{70}$ See, Supreme Court of India 2015.
} 
who had held or are holding high political and public offices, thought it appropriate to provide special courts for speedy trial for certain class of offences and for confiscation of properties involved. Accordingly, the Orissa Special Courts Act, 2006 was enacted as a money bill. The statute was challenged inter alia on the ground that it did not qualify to be passed as a money bill. The Court brushed aside the appellant's plea to review the speaker's certification of the bill as a 'money bill' with the following observation:

In our considered opinion, the authorities cited by the learned Counsel for the Appellants do not render much assistance, for the introduction of a bill, as has been held in Mohd. Saeed Siddiqui v. State of UP, comes within the concept of 'irregularity' and it does come with the realm of substantiality. What has been held in the Special Reference No. 1 of 1964 (supra) has to be appositely understood. The factual matrix therein was totally different than the case at hand as we find that the present controversy is wholly covered by the pronouncement in Mohd. Saeed Siddiqui v. State of UP and hence, we unhesitatingly hold that there is no merit in the submission so assiduously urged by the learned Counsel for the Appellants.

The Supreme Court once again blindly followed the precedent in Mohd. Saeed Siddiqui v. State of UP, which itself was based on an erroneous passing reference made by the court in Mangalore Ganesh Beedi Works v. State of Mysore.

Because of these three decisions of the Supreme Court, the current legal position in India is that the certification of a bill as 'money bill' by the speaker is beyond the judicial review powers of the Supreme Court. Not only does this position contradict the Supreme Court's own precedents on Articles 122 and 212 in cases of breach of legislative privilege under Articles 105 and 194, it is also at odds with the approach adopted across other common law jurisdictions.

\section{Judicial review in other jurisdictions}

\subsection{Australia}

The Commonwealth of Australia Constitution Act, 1900 does not use the term 'money bill'. Instead, section 53 of the Commonwealth of Australia Constitution Act, 1900 lays down that 'proposed laws' appropriating revenue or moneys, or imposing taxation can originate only in the House of Representatives (Lower House). For all other 'proposed laws', the Senate (Upper House) and the House of Rep- 
resentatives enjoy equal powers. Section 55 imposes certain limitations on 'laws' imposing taxation. ${ }^{71}$ The first paragraph of Article 55 mandates that laws imposing taxation will only deal with the imposition of taxation and the second paragraph restricts the scope of such laws to one subject of taxation at a time. ${ }^{72}$ The Australian jurisprudence on judicial review of constitutional procedure followed for 'proposed laws' and 'laws' has been markedly different.

The Australian High Court in Western Australia v. The Commonwealth held that section 53 is a procedural provision governing the intra-mural activities of the Parliament. It observed that the traditional view is that the court does not interfere in those activities. ${ }^{73}$ Similarly, in Northern Suburbs General Cemetery Reserve Trust $v$. The Commonwealth it held that a failure to comply with the dictates of a procedural provision, such as section 54, dealing with a 'bill' or a 'proposed law' is not contemporaneously justiciable and does not give rise to invalidity of the resulting Act when it has been passed by the two Houses of the Parliament and has received the royal assent. ${ }^{74}$

The significant distinction between sections 53 and 54 on one hand, and section 55 on the other, with regards to judicial review has been highlighted in the following passage from Osborne $v$. The Commonwealth: ${ }^{75}$

\footnotetext{
${ }^{71}$ Article 55 states: "Laws imposing taxation shall deal only with the imposition of taxation, and any provision therein dealing with any other matter shall be of no effect. Laws imposing taxation, except laws imposing duties of customs or of excise, shall deal with one subject of taxation only; but laws imposing duties of customs shall deal with duties of customs only, and laws imposing duties of excise shall deal with duties of excise only." See Article 55, Commonwealth of Australia Constitution Act, 19001900.

${ }^{72}$ The first paragraph has led to a unique practice in Australia of splitting tax bills into separate legislations, namely, a taxing law imposing taxation and an assessment law providing for the assessment, collection and the recovery of tax. It was the traditional view that an assessment law did not deal with the imposition of tax and hence must be kept separate, else it would preclude the Senate from amending the same. For example, the Goods and Services Act is the taxing law and the New Tax System (Goods and Services) Act, 1999 and the Taxation Administration Act, 1953 are the corresponding assessment laws. See, High Court of Australia 1959; The validity of the practice of splitting tax bills was affirmed by the Australian High Court. However, this affirmation was qualified with an exception that where there was no attempt of 'tacking' by the House of Representatives, a taxing law may deal with the assessment, collection and recovery of taxation without violating section 55. In the present context, 'tacking' refers to a practice whereby the House of Representatives abuses its power by including measures other than those related to taxation in a taxation law. See, High Court of Australia 2004.

${ }^{73}$ See paragraph 140, High Court of Australia 1995.

${ }^{74}$ Section 54 of the Commonwealth of Australia Constitution Act, 1900, mandates that the proposed law which appropriates revenue or moneys for the ordinary annual services of the Government shall deal only with such appropriation'. See, Commonwealth of Australia Constitution Act, 19001900.

${ }^{75}$ See, High Court of Australia 1911; The mandatory nature of section 55 and non-justiciability
} 
Secs. 53 and 54 deal with 'proposed laws'- that is, Bills or projects of law still under consideration and not assented to- and they lay down rules to be observed with respect to proposed laws at that stage. Whatever obligations are imposed by these sections are directed to the Houses of Parliament whose conduct of their internal affairs is not subject to review by a Court of law. Sec. 55, on the other hand, deals with proposals which have received the Royal assent, and which can be reviewed by Courts of law, if they offend against constitutional provisions.

Evidently, because of the unique usage of the phrases 'proposed law' and 'law' in the Commonwealth of Australia Constitution Act, 1900, the jurisprudence evolved by Australian courts treats contravention of constitutional provisions dealing with 'proposed laws' only to be internal affairs of the Houses and hence beyond the remit of judicial review. However, judicial review is possible on any alleged contravention of constitutional provisions dealing with 'laws'. Consequently, if a 'law' imposing taxation in Australia has any provision other than the imposition of taxation, the Australian High Court can exercise its judicial review powers to render such additional provision ineffective by virtue of section 55 of the Commonwealth of Australia Constitution Act, 1900.

\subsection{Canada}

The Canadian Constitution Act, 1867 does not use the term 'money bill' either. ${ }^{76}$ Section 53 mandates that a bill imposing a tax or appropriating public revenue must originate in the House of Commons. ${ }^{77}$ Section 54 then goes on to state that the House of Commons can adopt or pass such a bill only if it has been first recommended by the Governor General. ${ }^{78}$

Whether the process laid under sections 53 and 54 of the Constitution Act, 1867 is subject to judicial review has been a contentious issue in Canada. In In Reference

of sections 53 and 54 was further upheld. See, High Court of Australia 1995.

${ }^{76}$ The definition of 'money bill' itself has been a subject of long-standing debate in Canada. Additionally, the Senate and the House of Commons disagree on whether the power of the Senate is limited to initiate or amend a 'money bill'. See, Joan Small 1995.

${ }^{77}$ Section 53 states: Bills for appropriating any Part of the Public Revenue, or for imposing any Tax or Impost, shall originate in the House of Commons. See, Constitution Act, 18671867.

${ }^{78}$ Section 54 states: It shall not be lawful for the House of Commons to adopt or pass any Vote, Resolution, Address, or Bill for the Appropriation of any Part of the Public Revenue, or of any Tax or Impost, to any Purpose that has not been first recommended to that House by Message of the Governor General in the Session in which such Vote, Resolution, Address, or Bill is proposed. See, Constitution Act, $186 \%$. 
Re Agricultural Products Marketing Act, the constitutionality of the Agricultural Products Marketing Act, 1970 was challenged before the Canadian Supreme Court. The Agricultural Products Marketing Act, 1970 provided for an egg marketing scheme which imposed quotas for export of eggs by the provinces. The Canadian Egg Marketing Agency was created and empowered to impose levies and charges. The Supreme Court of Canada was asked to determine whether lack of Governor's recommendation under section 54 of the Constitution Act, 1867 before passing the Agricultural Products Marketing Act, 1970 rendered it unconstitutional. The Court concluded that Agricultural Products Marketing Act, 1970 did not impose any tax. The levies were merely ingredients of a regulatory scheme and fall to be considered as elements thereof. Therefore, the court did not conclusively decide whether the compliance with the procedure under sections 53 and 54 are subject to judicial review. However, the Court expressly negated the respondent's argument based on English precedents that it was only for the House of Commons to enforce the procedure under section 54 without judicial intervention. ${ }^{79}$

In In Reference Re Canada Assistance Plan, the Supreme Court of Canada was presented with another opportunity to reflect on this question. In 1990, the Canadian federal government, in order to reduce the federal budget deficit, decided to cut expenditures and limit the growth of payments made to financially stronger provinces under the Canada Assistance Plan. This change was embodied in the Government Expenditures Restraint Act, 1991. Under the Plan, the federal government concluded agreements with the provinces to share the cost of their expenditures on social assistance and welfare. The Lieutenant Governor in Council of British Columbia referred a constitutional question to British Columbia Court of Appeal: whether the terms of the agreement, the subsequent conduct of the Government of Canada pursuant to the agreement and the provisions of the Plan gave rise to a legitimate expectation that the Government of Canada would introduce no bill into Parliament to limit its obligation under the Agreement or the Plan without the consent of British Columbia? The Court observed: ${ }^{80}$

The formulation and introduction of a bill are part of the legislative process with which the courts will not meddle. So too is the purely procedural requirement in s. 54 of the Constitution Act, 1867 . That is not to say that this requirement is unnecessary; it must be complied with to create fiscal legislation. But it is not the place of the courts to interpose further procedural requirements in the legislative process.

On this basis, the Court refused to impose additional procedural obligation - like legitimate expectation - on the legislative powers of the Government but cate-

\footnotetext{
${ }^{79}$ See p. 1227, Supreme Court of Canada 1978.

${ }^{80}$ See, Supreme Court of Canada 1991.
} 
gorically stated that the procedure under section 54 must be complied with. ${ }^{81}$ Therefore, it can be concluded that Canadian courts have been inclined towards judicial review of the constitutional process of legislation-making by the Canadian legislature, although they have not had the occasion of using it to strike down any legislation.

\subsection{South Africa}

Section 77 of the Constitution of the Republic of South Africa, 1996 exhaustively defines 'money bill' while section 75 lays down the procedure of interaction between the National Assembly (Lower House) and the National Council of Provinces (Upper House) in passing a money bill. ${ }^{82}$ In South African Reserve Bank v. Mark Richard Shuttleworth, the Constitutional Court of South Africa touched upon these provisions of the Constitution of the Republic of South Africa, 1996. In 2003 the Minister of Finance announced that the Exchange Control Regulations would be relaxed enabling emigrants to unwind and export blocked assets subject to specified conditions. Mr Shuttleworth, who had made a considerable amount of money in South Africa, emigrated to the Isle of Man in 2001. In 2008, he applied to the Reserve Bank for permission to transfer around ZAR 1.5 billion out of South Africa. The request was granted by the Bank subject to an exit charge of $10 \%$. In 2009 he made a further transfer and once again an exit charge was extracted from him. Mr Shuttleworth requested that the Reserve Bank reconsider its decision to impose the charge. The Reserve Bank refused. This led to the litigation which ultimately went up to the Constitutional Court of South Africa. The question before the Court was whether the decision of the Reserve Bank of South Africa to impose a $10 \%$ exit levy payment on the value of the assets sought to be exported by Mr. Shuttleworth was constitutional. Mr. Shuttleworth contended that the levy amounted to a tax. The Reserve Bank's imposition of such tax was unconstitutional because it was not imposed through a statute passed by the Parliament in accordance with sections 75 and 77 of the Constitution of the Republic of South

\footnotetext{
${ }^{81}$ Legal scholars have also supported judicial review in case of non-compliance. This is because section 54 specifically provides that 'it shall not be lawful' to pass a bill described therein without a royal recommendation. Effect must be given to these words. If the courts will not review the actions under section 54, then Parliament is free to ignore the prescription that it shall not be lawful'. Accordingly, it has been suggested that 'The legal question can never be resolved internally; that is, as between the two Chambers. Instead, one must look to the courts'. See, Joan Small 1995.

${ }^{82}$ Section $75(\mathrm{c})$ states that if the Council rejects the money bill or passes it subject to amendments, the Assembly must reconsider the bill and may pass it with or without such amendments. See, Constitution of the Republic of South Africa, 19961996.
} 
Africa, 1996. Although the Apex Court rejected Mr. Shuttleworth's contention that the levy was a tax, it observed: ${ }^{83}$

If the exit charge was directed at raising revenue and therefore was a national tax, it would be hit by the formalities for adopting a money Bill. On the other hand, if the exit charge was not calculated to raise revenue and thus was not akin to a money Bill, it would not have to comply with section 9(4). Let it suffice to note that sections 75 and 77 of the Constitution have superseded the provisions of section 9(4) of the Act. This means that a Bill that is 'calculated to raise revenue' by imposing a national tax must comply with the constitutional requirements for a money Bill.

Evidently the Court exercised its powers of judicial review in this case and concluded that since the impugned exit charge was not 'calculated to raise revenue', it was not unconstitutional under Constitution of the Republic of South Africa, 1996.

\subsection{United States of America}

The Constitution of the United States of America does not use the term "money bill'. Instead, the "Origination Clause" gives the House of Representatives (Lower House) the power to originate bills for "raising revenue". ${ }^{84}$ Further, it prohibits the Senate from proposing any amendment that would turn a revenue measure into a non-revenue measure. ${ }^{85}$

The US Supreme Court in Marshall Field $\&$ Co. v. Clark developed the 'enrolled bill' doctrine which requires courts to accept the signatures of the Speaker of the House and President of the Senate on the 'enrolled bill' as 'complete and unimpeachable' evidence that a bill has been properly and constitutionally enacted. ${ }^{86}$

\footnotetext{
${ }^{83}$ See paragraph 62, Constitutional Court of South Africa 2015.

${ }^{84}$ Article I, Section 7, clause 1 is referred to as the 'Origination Clause'. This clause states: All Bills for raising Revenue shall originate in the House of Representatives; but the Senate may propose or concur with amendments as on other Bills. See, The Constitution of the United States of America 1787.

${ }^{85}$ See p. 1, James V. Saturno 2011.

${ }^{86}$ See, Court 1892; Practical concerns have emerged regarding the application of the 'enrolled bill' rule. For instance, there has been evidence to suggest that the House and Senate passed different versions of the bill leading up to the enactment of the Deficit Reduction Act, 2005. Six cases have challenged the constitutionality of that legislation. Yet, the courts have dismissed all these challenges on the ground that the 'enrolled bill' rule precludes judicial review. See, David Sandler 2008, p. 214.
} 
However, this doctrine has not restricted the Supreme Court from using its judicial review powers to hear constitutional challenges based on alleged violation of the Origination Clause. ${ }^{87}$ For instance, in United States v. Munoz-Flores, a statute was challenged before the Supreme Court on the ground that its enactment process violated the Origination Clause in The Constitution of the United States of America. The government argued that judicial invalidation of a law for breach of the Origination Clause would evince a lack of respect for the House's determination. The Court rejected the government's argument and went on to exercise its powers of judicial review. Finally, it concluded that the statute was not a 'bill for raising revenue' and therefore, did not violate the Origination Clause. While rendering the majority judgement, Justice Marshall reasoned: ${ }^{88}$

To survive this Court's scrutiny, the "law" must comply with all relevant constitutional limits. A law passed in violation of the Origination Clause would thus be no more immune from judicial scrutiny because it was passed by both Houses and signed by the President than would be a law passed in violation of the First Amendment.

Effectively, under American law, allegation of breach of a constitutional procedure in enacting a law is a valid ground for judicial review. ${ }^{89}$ Such judicial review cannot be restricted merely because the Speaker of the House and President of the Senate have signed off the bill. Although the US Supreme Court has primarily limited its role to determining whether a measure is a 'bill for raising revenue', cases like United States $v$. Munoz-Flores have shown that the House is not the ultimate authority with respect to determining the meaning or enforcement of its prerogatives under the Origination Clause. ${ }^{90}$

\subsection{Pakistan}

Articles 73 of the Constitution of the Islamic Republic of Pakistan lays down the procedure with respect to money bill along with an exhaustive definition. Like the Constitution of India, Article 73(4) of the Constitution of the Islamic Republic of Pakistan gives finality to the decision of the speaker of the National Assembly if any

\footnotetext{
${ }^{87}$ One commentator has gone to the extent of claiming that the decision of the Supreme Court in United States v. Munoz-Flores has rendered the 'enrolled bill' doctrine doctrinally unstable. See, Bar-Siman-Tov 2009.

${ }^{88}$ See Court 1990.

${ }^{89}$ Only a handful Origination Clause challenges have been made to the US Supreme Court. These cases have questioned whether the challenged act is actually a 'bill for raising revenue' that triggers the Origination Clause's requirements. See p. 460, Tessa L. Dysart 2015.

${ }^{90}$ See, James V. Saturno 2011.
} 
question arises as to whether a bill is a money bill or not. Like the Constitution of India, Article 73(5) of the Constitution of the Islamic Republic of Pakistan mentions that every money bill presented to the President for assent must bear a certificate under the hand of the speaker of the National Assembly that it is a money bill. However, unlike the Constitution of India, Article 73(5) of the Constitution of the Islamic Republic of Pakistan states that 'such certificate shall be conclusive for all purpose and shall not be called in question'. In spite of such explicit conclusive status given to the speaker's certificate, the Pakistan Supreme Court has not only exercised judicial review over the speaker's certificate, it has also struck down legislation enacted as money bill as unconstitutional for failing to comply with the constitutional procedure.

In Sindh High Court Bar Association v. Federation of Pakistan, the amendment to Supreme Court (Number of Judges) Act, $199^{7}$ through a money bill - the Finance Act, 2008 - was challenged as unconstitutional. Since the amendment to the Supreme Court (Number of Judges) Act, 1997 did not fall within the definition of 'money bill' in Article 73, the Court declared it unconstitutional and referred it back to the Parliament. ${ }^{91}$

In Mir Muhammad Idris v. Federation of Pakistan, the question before the Supreme Court was whether section 11(3)(d) of the Banks Nationalisation Act, 1974, which related to the appointment of Chairman, President and members of the Board of the National Bank of Pakistan, could have been amended by the Finance Act, 2007 - a money bill. Under section $11(3)(d)$ a person could be appointed as President of the National Bank of Pakistan for not more than two terms. This provision had been amended multiple times through ordinances and finally through the Finance Act, 2007 to allow the respondent to hold office. The Supreme Court struck down this amendment since it did not fall within the definition of a 'money bill' within the meaning of Article 73 of the Constitution of the Islamic Republic of Pakistan and lacked the approval of both the Houses of Parliament. ${ }^{92}$

Similarly, in Muhammad Asraf Tiwana v. Pakistan, a savings clause was added to section 5 of the Securities and Exchange Commission of Pakistan Act, 1997 through a money bill - the Finance Act, 2003 - to prevent actions and proceedings undertaken by the Commission from being invalidated due to vacancy or defect in constitution of the Commission. This amendment was challenged for being beyond the scope of the definition of 'money bill' under Article 73 of the Constitution of the Islamic Republic of Pakistan. The Supreme Court struck down the amendment as unconstitutional since the impugned amendment did not fall within the scope

\footnotetext{
${ }^{91}$ See, Supreme Court of Pakistan 2009.

${ }^{92}$ See paragraph 11, Supreme Court of Pakistan 2011.
} 
of the definition of 'money bill'. ${ }^{93}$

Again in Federation of Pakistan v. Durrani Ceramics 8 Others, the Gas Infrastructure Development Cess Act, 2011 was enacted as a money bill for the stated purpose of collection of the cess for the construction of pipelines for importing natural gas and for equalization of gas prices with other imported fuels such as LNG from most gas consumers. It was challenged as unconstitutional on the ground that it did not fall within the definition of 'money bill' under Article 73 of the Constitution of the Islamic Republic of Pakistan. The Supreme Court concluded that the imposition was not a tax but a fee. Accordingly, it could not have been imposed through a money bill and on this ground the statute was struck down. ${ }^{94}$

Evidently, the Pakistan Supreme Court has been extremely active in exercising judicial review over the speaker's certification of bills as 'money bills' even though Article 73 of the Constitution of the Islamic Republic of Pakistan clearly states that 'such certificate shall be conclusive for all purpose and shall not be called in question'.

\section{Conclusion}

Detailed review of the drafting history as well as the text of the Constitution of India suggests that in India legislative proceedings are immune from judicial review only on the ground of 'irregularity of procedure'. In other words, if a House commits breach of any procedure in any rule made by itself or in any legislation that the Houses themselves had passed, such breach is an internal matter for the House itself to act on. It is not open to judicial review. But if a House commits a breach of any constitutional procedure, such breach is open to judicial review. A contrary interpretation would effectively render the constitutional design of a bicameral legislative system completely redundant. The speaker can certify each and every bill to be a 'money bill', practically dispensing with the need for the Upper House. It is submitted that when a speaker incorrectly certifies a bill as a 'money bill' under Article 110(4) or 199(4), such incorrect certification is no more an 'irregularity of procedure' but a breach of a cardinal constitutional provision. Therefore, the Indian Supreme Court can legitimately exercise its judicial review powers to review the speaker's certificate and strike down any law passed as 'money bill' in contravention of the very definition of 'money bill' under the Constitution of India.

\footnotetext{
${ }^{93}$ See paragraph 41, Supreme Court of Pakistan 2013.

${ }^{94}$ See paragraph 23, Supreme Court of Pakistan 2014.
} 
This position is supported by precedents across common law jurisdictions. Foreign courts recognise the need for exercise of judicial review to ensure legislative compliance with constitutional procedure. This is especially necessary to avoid the possibility of the age old problem of 'tacking', where the Lower House can incorporate unrelated provisions within a money bill to avoid interference by the Upper House. Pakistan, which has very similarly worded constitutional provisions on finality of the Speaker's decision, has been particularly vigilant in exercising its judicial review powers in this regard to strike down legislations camouflaged as money bills.

Even the Indian Supreme Court's own jurisprudence with respect to judicial review of legislative privileges under Articles 105 and 194 clearly distinguishes between 'procedural irregularity' and 'procedural illegality'. The Supreme Court has in a catena of cases used its judicial review powers in legislative affairs on the ground that the allegations were of 'procedural illegality' and not merely 'procedural irregularity'. Moreover, the 'final' status granted to the Speaker's decision under Articles 110 and 199 cannot immune such decision from judicial review either. As noted earlier, the Supreme Court itself has exercised judicial review over other types of 'final' decisions made by various constitutional authorities including the Speaker under other provisions of the Constitution of India. Yet, the same Supreme Court has failed to extend the same principles to review legislations incorrectly enacted as money bills on the erroneous logic that Articles 112, 212 and 255 render such patent illegality immune from judicial scrutiny. Jairam Ramesh $v$. Union of India offers the Supreme Court one more opportunity to rectify this contradiction in its own jurisprudence and settle the law regarding its powers of judicial review of the speaker's certification of a bill as 'money bill'. 


\section{References}

Aadhar Act, 2016 (2016). Aadhar (Targeted delivery of financial and other subsidies, benefits and services) Act, 2016. URL: https://uidai.gov.in/images/ targeted_delivery_of_financial_and_other_subsidies_benefits_and_ services_13072016.pdf (visited on Sept. 10, 2016).

Agricultural Products Marketing Act, 1970 (1970).

Alok Prasanna Kumar (2016). "Why the Centre's dubious use of money bills must not go unchallenged". In: Scroll.in. URL: https://scroll.in/article/ 807861 / why - the-centres-dubious-use-of - money-bills-must-not-gounchallenged (visited on Feb. 10, 2017).

Anupam Chander (1991). "Sovereignty, Referenda, and the Entrenchment of a United Kingdom Bill of Rights". In: Yale Law Journal 101, pp. 457-480.

Arvind P. Datar and Rahul Unnikrishnan (2016). "Making a money bill of it". In: The Indian Express (Jan. 12, 2016). URL: http://indianexpress . com/ article / opinion / columns / making-a-money-bill - of - it/ (visited on Jan. 12, 2016).

B. Shiva Rao, ed. (2012). The Framing of the Indian Constitution: Selected Documents. Vol. 3. Universal Law Publishing Co. Pvt. Ltd.

Bar-Siman-Tov, Ittai (2009). "Legislative Supremacy in the United States?: Rethinking the 'Enrolled Bill' Doctrine". In: Georgetown Law Journal.

BS Reporter (2015). "Govt withdraws PDMA, RBI Bill provisions from Finance Bill". In: Business Standard (May 1, 2015). URL: http : / / www . businessstandard.com/article/economy-policy/govt-withdraws-pdma-rbi-billprovisions-from-finance-bill-115043000524_1.html (visited on May 1, 2015).

Commonwealth of Australia Constitution Act, 1900 (1900).

Constitution Act, 1867 (1867).

Constitution of India (1949).

Constitution of Ireland, 1937 (1937).

Constitution of the Islamic Republic of Pakistan (1973).

Constitution of the Republic of South Africa, 1996 (1996).

Constitutional Court of South Africa (2015). South African Reserve Bank v. Mark Richard Shuttleworth. Cases CCT 194/2014, [2015] ZACC 17. June 18, 2015.

Court, United States Supreme (1892). Marshall Field 86 Co. v. Clark. 143 U.S. 649.

- (1990). United States v. Munoz-Flores. 495 U.S. 385, 398 (1990).

David Sandler (2008). "Forget What You Learned in Civics Class: The "Enrolled Biill Rule" and Why It's Time to Overrule Field v. Clark". In: Columbia Journal of Law and Social Problems, pp. 213-267. 
Durga Das Basu (2012). Commentary on the Constitution of India. Vol. 8. Lexis Nexis.

Finance Act 2004 (2004).

Finance Act 2012 (2012).

Finance Act 2015 (2015).

Finance Act 2016 (2016).

Finance Bill 2017 (2017).

Fiscal Responsibility and Budget Management Act 2003 (2003).

FEMA (1999). Foreign Exchange Management Act 1999.

FP Staff (2016). "GST Bill in Rajya Sabha: Behind Arun Jaitley-Chidambaram bonhomie divisions are deep". In: Firstpost (Aug. 3, 2016). URL: http: //www . firstpost . com / politics / gst - bill - in - rajya - sabha - behind - arun jaitley-chidambaram-bonhomie-the-divisions-are-deep-2932710 . html (visited on Aug. 3, 2016).

Government of India Act, 1919 (1919).

Government of India Act, 1935 (1935).

High Court of Australia. Northern Suburbs General Cemetery Reserve Trust v. The Commonwealth. (1993) 176 CLR 555.

- (1911). Osborne v. The Commonwealth. (1911) 12 CLR 321. May 31, 1911.

- (1959). Re Dymond. (1959) 101 CLR 11. Apr. 27, 1959.

- (1995). Western Australia v. The Commonwealth. (1995) 183 CLR 373. Sept. 25, 1995.

- (2004). Permanent Trustee Australia Limited v. Commissioner of State Revenue. [2004] HCA 53. Nov. 12, 2004.

James Madison (1788). The Senate. Federalist No. 62. The Federalist Papers.

James V. Saturno (2011). The Origination Clause of the U.S. Constitution: Interpretation and Enforcement. CRS Report for Congress. Congressional Research Service.

Joan Small (1995). "Money Bills and the use of the Royal recommendation in Canada: Practice versus principle?" In: Ottawa Law Review 27 (1 1995), pp. 3358.

King v. Arundel (1616). Hobart's Rep. 109. Order.

K.R. Srivats (2015). "Bankruptcy code referred to Joint Select Committee of Parliament". In: The Hindu BusinessLine (Dec. 23, 2015). URL: http : / / www . thehindubusinessline . com / economy / bankruptcy - code - referred - to joint-select-committee - of - parliament / article8021733 . ece (visited on Dec. 23, 2015).

Lucas Prakke (2006). "Swamping the Lords, packing the court, sacking the King". In: European Constitutional Law Review 2 (1 2006), pp. 116-146.

Michael A.R. Graves, ed. (1987). Elizabethan Parliaments, 1559-1601. Longman. 
M.R. Madhavan (2016). "Name of the bill". In: The Indian Express (Apr. 15, 2016). URL: http : / / indianexpress . com / article / opinion / columns / aadhaarbill-money-bill-name-of-the-bill-2754080/ (visited on Sept. 21, 2016).

Neal Blewett (1972). The Peers, the Parties and the People: The General Elections of 1910. Macmillan.

Parliament Act, 1911 (1911). URL: http://www. legislation.gov.uk/ukpga/ Geo5/1-2/13/contents (visited on Feb. 10, 2016).

Parliament Act, 1911 (1911).

Parliament of Canada (2016). House of Commons Procedure and Practice. Historical Perspective. URL: http: //www . parl.gc .ca/procedure-book-livre/ document . aspx?sbdid $=f 26 e b 116-b 0 b 6-490 c-b 410-33 d 985 b c 9 b 6 b \& s b p i d x=$ 4\#_ftnref6 (visited on Feb. 9, 2016).

Parliament of India (2016). Constituent Assembly Debates (Proceedings). Volume VIII. URL: http : / / parliamentofindia . nic . in/ls / debates / vol8p6 . htm (visited on Sept. 20, 2016).

Payments and Settlements Act, 2007 (2007).

P.D.T. Achary (2016). "Show me the money". In: The Indian Express (Mar. 12, 2016). URL: http://indianexpress . com/article/opinion/columns/showme-the-money-4/ (visited on Sept. 21, 2016).

Pratap Bhanu Mehta (2016). "Privacy after Aadhar". In: The Indian Express (Mar. 26, 2016). URL: http://indianexpress.com/article/opinion/columns/ privacy-after-aadhaar-money-bill-rajya-sabha-upa/ (visited on Sept. 21, 2016).

Pratik Datta, Shivangi Tyagi, Shefali Malhotra (2016). The controversy about Aadhaar as a money bill. Ajay Shah's blog. URL: https: / / ajayshahblog. blogspot . in/2016/03/the-controversy-about-aadhaar-as-money . html (visited on Mar. 20, 2016).

Reserve Bank of India Act, 1934 (1934).

Securities Exchange Board of India, 1992 (1992).

Select Committee on the Constitution (2011). Money Bills and Commons Financial Privilege. Report of Session. House of Lords, Feb. 3, 2011. URL: http://www . publications . parliament.uk/pa/ld201011/ldselect/ldconst/97/97 .pdf (visited on Jan. 21, 2016).

Sir Thomas Erskine May (1883). A Treatise on The Law, Privileges, Proceedings and Usage of Parliament. Ninth. Butterwoth. URL: https : / / ia801409.us . archive.org/9/items/treatiseonlawpri00maytrich/treatiseonlawpri00maytrich. pdf (visited on Jan. 21, 2016).

Specified Bank Notes (Cessation of Liabilities) Bill, 2017 (2017). 
Suhrith Parthasarathy (2017). "What exactly is a money bill?" In: Hindu. URL: http : / / ww . thehindu . com/opinion/lead/what-exactly-is-a-moneybill/article17372184. ece (visited on Feb. 27, 2017).

Supreme Court of Canada (1978). In Reference Re Agricultural Products Marketing Act. [1978] 2 S.C.R. 1198. Jan. 19, 1978.

- (1991). In Reference Re Canada Assistance Plan. [1991] 2 S.C.R. 525. Aug. 15, 1991.

Supreme Court of India (1960). Pandit M.S.M. Sharma v. Dr. Shree Krishna. AIR 1960 SC 1186. Aug. 1, 1960.

- (1962). Mangalore Ganesh Beedi Works v. State of Mysore. AIR 1963 SC 589. Sept. 25, 1962.

- (1964). Special Reference No. 1 of 1964. AIR 1965 SC 745. Sept. 30, 1964. URL: http: //judis.nic. in/supremecourt/imgs1. aspx?filename=3164 (visited on Feb. 19, 2016).

- (2007). Raja Ram Pal v. Hon'ble Speaker, Lok Sabha. W.P. (C) No.1 of 2006. Jan. 10, 2007.

- (2014). Mohd. Saeed Siddiqui v. State of UP. AIR 2014 SC 2051. Apr. 24, 2014. URL: http : / / judis . nic . in/supremecourt/imgs1 . aspx?filename $=41456$ (visited on Feb. 22, 2016).

- (2015). Yogendra Kumar Jaiswal v. State of Bihar. 2015 (13) SCALE 508. Dec. 10, 2015. URL: http : / / supremecourtofindia . nic . in / FileServer / 2015-12-10_1449731938.pdf (visited on Feb. 22, 2016).

- (2016). Jairam Ramesh v. Union of India. Writ Petition (Civil) 231/2016. Order. May 10, 2016.

Supreme Court of Pakistan (2009). Sindh High Court Bar Association v. Federation of Pakistan. PLD 2009 SC 879. Judgment.

- (2011). Mir Muhammad Idris v. Federation of Pakistan. Judgment. Jan. 14, 2011.

- (2013). Muhammad Asraf Tiwana v. Pakistan. Judgment. Apr. 12, 2013.

- (2014). Federation of Pakistan v. Durrani Ceramics 8 Others. Judgment. Aug. 22, 2014.

Tax Bills - Resolutions (1860). House of Commons. July 5, 1860. URL: http: / / hansard . millbanksystems . com / commons / 1860 / jul / 05 / tax-bills resolutions (visited on Jan. 21, 2016).

Tessa L. Dysart (2015). "The origination clause, the Affordable Care Act, and the indirect constitutional violations". In: Cornell Journal of Law and Public Policy, pp. 451-492.

The Constitution of the United States of America (1787).

GST Constitution Amendment Bill (2014). The Constitution (One hundred and twenty-second amendment) Bill, 2014. URL: http: / / www . prsindia . org / 
uploads / media / Constitution \% 5C \% 20122nd / Constitution \% 5C \% 20 \% 5C \% $28122 \mathrm{nd} \% 5 \mathrm{C} \% 29 \% 5 \mathrm{C} \% 20 \% 5 \mathrm{C} \% 28 \mathrm{~A} \% 5 \mathrm{C} \% 29 \% 5 \mathrm{C} \% 20 \mathrm{bill}$. pdf (visited on Sept. 10, 2016).

UP Lokayukta and Up-Lokayuktas (Amendment) Act, 2012 (2012).

Uttar Pradesh Lokayukta and Up-Lokayuktas Act, 1975 (1975). 


\section{MORE BYTHE AUTHORS}

- Datta, Pratik (2016). Demonetisation needs a parlia-

The authors are Consultants mentary law to be fool-proof. NIPFP blogpost, Dec 6.

\section{MORE IN THE SERIES}

- Rao, M.G. (2017) Budget 2017-18: Business as Usual,WP No. I9I (March)

- Rao, M.G., and Kumar, S. (20I7). Envisoning Tax Policy for Accelerated Development in India, WP No. 190 (March)

- Patnaik, I., Felman, J., and Shah,A. (2017).An Exchange Market Pressure Measure for Cross Country Analysis, WP No. 189 (February)

National Institute of Public Finance and Policy,

18/2, Satsang Vihar Marg, Special Institutional Area (Near JNU),

New Delhi I 10067

Tel. No. 26569303, 26569780, 26569784

Fax: 9 I- I I-26852548

www.nipfp.org.in 